\title{
Franco Modigliani and Keynesian Economics
}

This book follows the intellectual path of Franco Modigliani, Nobel Prize winner and one of the most influential Keynesian economists of the twentieth century, tracing his development and examining the impact of his research.

The book begins with Modigliani's early work as a young law student in 1930s Italy and traces his development through his emigration to the U.S., his introduction to Keynes' General Theory at the New School for Social Research and his seminal 1944 article on Keynesian and classical economics. The book also discusses Modigliani's pioneering theory of savings: the life-cycle hypothesis with Richard Brumberg, further developed with Albert Ando, his contributions to decision-making under uncertainty and, finally, Modigliani's collaboration with the Federal Reserve Board for the building of its first macroeconometric model for the U.S. economy. The book argues that although Modigliani is placed amongst the most prominent Keynesian economists, if we look to his published works only, and with the exception of the 1944 article, his connections with Keynesian theory appears of secondary importance until the beginning of the 1960s when he joined MIT. Moreover, since then his contributions are much more on policy issues rather than theoretical ones.

This is the first book to place Modigliani's thought in its proper historical and intellectual context, showing how it related to wider economic concerns and possible policy solutions. It will be of interest to scholars in the history of economic thought, and especially post-war American Keynesian economics.

Antonella Rancan is Associate Professor of Economics at the University of Molise, Italy. 
Perspectives in Economic and Social History

Series Editors: Andrew August and Jari Eloranta

Labor Before the Industrial Revolution

Work, Technology and their Ecologies in an Age of Early Capitalism

Edited by Thomas Max Safley

Workers, Unions and Payment in Kind

The Fight for Real Wages in Britain, 1820-1986

Christopher Frank

A History of States and Economic Policies in Early Modern Europe Silvia A. Conca Messina

Fiscal Policy in Early Modern Europe

Portugal in Comparative Context

Rodrigo da Costa Dominguez

Workers, Unions and Truck Wages in British Society

The Fight for Real Wages, 1820-1986

Christopher Frank

Early Modern Overseas Trade and Entrepreneurship

Nordic Trading Companies in the Seventeenth Century

Kaarle Wirta

Credit and Debt in Eighteenth Century England

An Economic History of Debtors' Prisons

Alexander Wakelam

Franco Modigliani and Keynesian Economics

Antonella Rancan

For more information about this series, please visit: www.routledge.com/ series/PESHSeries $\backslash$ Perspectives in Economic and Social History.doc 


\title{
Franco Modigliani and Keynesian Economics
}

\author{
Antonella Rancan
}


First published 2020

by Routledge

2 Park Square, Milton Park, Abingdon, Oxon OX14 4RN

and by Routledge

52 Vanderbilt Avenue, New York, NY 10017

Routledge is an imprint of the Taylor \& Francis Group, an informa business

(C) 2020 Antonella Rancan

The right of Antonella Rancan to be identified as author of this work has been asserted by her in accordance with sections 77 and 78 of the Copyright, Designs and Patents Act 1988.

All rights reserved. No part of this book may be reprinted or reproduced or utilised in any form or by any electronic, mechanical, or other means, now known or hereafter invented, including photocopying and recording, or in any information storage or retrieval system, without permission in writing from the publishers.

Trademark notice: Product or corporate names may be trademarks or registered trademarks, and are used only for identification and explanation without intent to infringe.

British Library Cataloguing-in-Publication Data

A catalogue record for this book is available from the British Library

Library of Congress Cataloging-in-Publication Data

Names: Rancan, Antonella, author.

Title: Franco Modigliani and Keynesian economics : theory, facts and policy / Antonella Rancan.

Description: Abingdon, Oxon ; New York, NY : Routledge, 2020. | Series: Perspectives in social and economic history | Includes bibliographical references and index.

Identifiers: LCCN 2020002095 (print) | LCCN 2020002096 (ebook) | ISBN 9781848935013 (hardback) | ISBN 9781003047032 (ebook)

Subjects: LCSH: Modigliani, Franco. | Economists—Italy. | Keynesian economics.

Classification: LCC HB109.M63 R36 2020 (print) | LCC HB109.M63

(ebook) | DDC 330.15/6-dc23

LC record available at https://lccn.loc.gov/2020002095

LC ebook record available at https://lccn.loc.gov/2020002096

ISBN: 978-1-848-93501-3 (hbk)

ISBN: 978-1-003-04703-2 (ebk)

Typeset in Bembo

by Apex CoVantage, LLC 


\section{Contents}

Introduction: Modigliani’s Keynesianism and beyond $\quad 1$

1 Modigliani before Modigliani $\quad 7$

2 Approaching Keynes and American Keynesianism 22

3 Keynesian economics in between corporative and socialist economics

4 Modigliani at the University of Illinois: "The Bowen war" and McCarthyism

5 Uncertainty and expectations: Modigliani at Carnegie Tech 88

6 The life cycle savings in an unstable economy 116

7 Becoming Keynesian 139

Index

170 
$\because$ Taylor \& Francis

Taylor \& Francis Group

http://taylorandfrancis.com 


\section{Introduction}

\section{Modigliani’s Keynesianism and beyond}

This book is an attempt to broadly outline the intellectual path of Franco Modigliani (1918-2003), who emigrated to the United States in 1939 to escape Mussolini's racial laws and took American citizenship a few years later, deciding not to come back to Italy at the end of WWII. In 1985 Modigliani was awarded the Royal Bank of Sweden Prize in Economic Science in Memory of Alfred Nobel for his pioneering theory of savings, the life cycle hypothesis (with Richard Brumberg), and for the Modigliani-Miller theorem (with Merton H. Miller), a cornerstone of modern theory of finance.

Although both achievements are not strictly related to postwar Keynesian macroeconomics, Modigliani is especially known as a leading Keynesian, and his name is associated with that of other prominent American Keynesians and Nobel Laureates: Lawrence Klein, Paul Samuelson, Robert Solow and James Tobin, who marked the U.S. postwar macroeconomics and its policy agenda.

Modigliani's (1944) seminal article on Keynes's involuntary unemployment and wage rigidity is recalled among the ones that set the basis of the neoclassical synthesis, that is, an interpretation of Keynes's macroeconomics within the neoclassical framework. "I consider myself a Keynesian", Modigliani said in his conversation with Barnett and Solow (2000, p. 230) as in several other interviews and in his autobiography (Modigliani 2001). He also explained what he meant for "being a Keynesian": to know that "the system does not automatically tend to full employment without appropriate policies. Prices flexibility will not produce full employment, and therefore unemployment is always due to an insufficiency of real money" (Barnett and Solow 2000, p. 230), thus emphasizing what he considered "fundamental" in the Keynesian system: to recognize the limits of the market self-adjusting mechanisms, of the crucial role of money to explain unemployment and to believe in the effectiveness of policy actions. Modigliani also placed the research program he pursued all over his academic career within the context of postwar American Keynesianism. In the "Introduction" to his Collected Papers, he outlined his scientific endeavor as "dominated" by "sorting out" the lasting contributions of the Keynesian revolution, that is, to integrate the main building blocks of the General Theory with the neoclassical postulate of rational maximizing behavior; to empirically estimate and test the resulting theories; and to apply these results to policy issues (see Modigliani 1980, vol. 1, p. xi). Such basic building blocks 


\section{Introduction}

are the consumption function, the investment function, the demand for and supply of money and other deposits and the mechanism determining wages and prices - the "Achilles's heel of macroeconomic analysis" as Modigliani puts it (Modigliani 1980, vol. 1, pp. xi-xii).

By outlining Modigliani's intellectual path, the book suggests that Modigliani's connections with the Keynesian theory appears of secondary importance until the beginning of the 1960s, when he joined MIT. In the late 1940s and 1950s, the years Modigliani defined as his most productive ones, he was working on consumption and savings behavior within the neoclassical optimization framework, on firms' production planning under uncertainty, on oligopoly theory and the theory of corporate finance. Although it is true that Modigliani's work on macroeconomics moved in that direction, being especially devoted to enlarge the perspective of marginal analysis by applying its tools to Keynesian macroeconomics, it is also true that Modigliani's most important contributions originated from a multifaceted intellectual context in which Keynesian developments were not central, and partly different from that of prominent Keynesians to whom his name is associated. ${ }^{2}$

The 1944 Econometrica article of the twenty-six-year-old economist was not followed by further developments in the 1940s and 1950s. Only in 1963 did Modigliani return to publish on Keynesian and classical economics with a more elaborate analysis along the lines began almost twenty years before. While his unfinished and unpublished work over the 1950s showed a fil rouge between the two models, in his published studies Modigliani's main interests seem to move in different directions.

In other words, it is only with Modigliani's arrival at MIT in 1962, and the beginning of the collaboration with the most important public institutions such as the Federal Reserve Board that Modigliani's image as a Keynesian takes full shape, permeating his previous works. It was in connection with the peak of the Keynesian and monetarist academic, intellectual and political dispute. From then Modigliani became fully engaged with Keynesian macroeconomics, especially with its translation in a macroeconometric model, to be delivered to policy makers. In fact, Oliver Blanchard in the New Palgrave (2008, pp. 635-636) will define the Federal Reserve Board, MIT and University of Pennsylvania macroeconometric model the "apotheosis" of the neoclassical synthesis, and the model was one of the main targets of Lucas's new classical macroeconomics over the late 1970s and 1980s. Modigliani himself saw in that macroeconometric model an attempt to put together the most relevant contributions of postwar economics in a large-scale, consistent model. The importance Modigliani ascribed to the Federal Reserve Board, MIT and University of Pennsylvania model is evident by the fact that with the exception of the 1944 and the 1963 articles, volume 1 of his Collected Papers devoted to his essays in (Keynesian) macroeconomics gathers papers Modigliani wrote in connection with its building.

Before his arrival at MIT, Modigliani went around different universities becoming part of different communities of academic economists from the 
European émigrés of the New School for Social Research to Chicago University and the Cowles Commission, then he moved to the University of Illinois and in 1952 he joined the new Graduate School of Industrial Administration of the Carnegie Institute of Technology (now Carnegie Mellon University). Finally, ten years later he joined MIT, Samuelson and Solow, spending most of his time building the macroeconometric model for the Federal Reserve Board and intervening in policy issues. At MIT Modigliani accomplished his intellectual journey (and Keynesian adventure).

Modigliani's emphasis on market failures and his focus on wage and price behavior to distinguish between classical and Keynesian economics and on the active role of policy makers have a background that goes beyond American Keynesianism. Modigliani approached economics at the university during the fascist period in Italy when only corporative economics was taught. He recalled that he began to be interested in economic problems and to think about himself as an economist when translating German articles into Italian. He also began to write a few essays on price control and international trade whose fil rouge was a critique of classical economics with a highly rhetorical language (see Chapter 1). In other words, his reasoning on the relationships among public policies, market forces and individual choice began before his discovery of Keynes's General Theory, within the context of the corporative economics (he labeled "new economics").

He learned the tools of economic analysis at the New School as his Italian education was in humanities (classical studies and a degree in law), especially under Jacob Marschak who pursued an eclectic, anti-dogmatic and mathematical approach to economics and whose intellectual debt Modigliani has always accomplished and emphasized. Modigliani's 1944 Keynesian model originated from a quite unique intellectual context. He first encountered Keynes's General Theory through Marschak's classes, Oskar Lange's seminars and discussions with Abba Lerner and after having read Hicks's "Keynes and the Classics" (see Chapter 2). When he encountered Keynes's General Theory, he had already read the Keynes of the end of laissez-faire and national autarchy. Soon after his PhD dissertation, between 1944 and 1945, Modigliani returned to reasoning on the evolution of the capitalistic system and its failures, as he did in the 1930s, in an Italian article on the organization of a socialist economy (see Chapter 3).

At the New School he became associate professor and chief statistician of the Institute of World Affairs, founded and led by Hans Neisser, until 1948. With Neisser he was engaged with the building of a macroeconometric model for the world economy and came to work on long run and cyclical savings behavior, the starting point of the life cycle hypothesis (see Chapter 3). In 1948 he went to Chicago University with a six-month fellowship provided by Theodore Schultz, and soon after he joined the University of Illinois, whose Economics Department was at the center of a generational change being formed by a group of young mathematical and empirical economists. He was called to direct an interdisciplinary project, Expectations and Business Fluctuation, to which he was committed over the 1950s, when he moved to the new Graduate School of Industrial Administration of Carnegie Tech, whose research agenda 


\section{Introduction}

set the basis for modern management science. There, Modigliani was part of an extraordinary research group formed by Lee Bach, Charles Holt, John Muth and Herbert Simon, working on firms' production planning behavior under uncertainty from which Muth's rational expectations, on the one side, and Simon's bounded rationality, on the other, emerged (see Chapters 4 and 5).

Over the 1950s Modigliani went on to work on consumption and savings behavior, a typically Keynesian topic that attracted the attention of most economists both because of the widespread concern about over savings, and "to solve" the intellectual puzzle of reconciling short- and long-run savings behavior (see Chapter 6). Modigliani and Richard Brumberg worked contemporarily on the microeconomic and macroeconomic aspects of their theory and established explicit connections with the Keynesian theory. However, these connections are only discussed in a section devoted to the Pigou effect of a paper longer than seventy pages that remained unpublished until Modigliani's Collected Papers (vol. 2, 1980). When Modigliani began to work on the savings function, he was much more interested in the possibility of its measuring, testing hypotheses and ability to forecast rather than in providing a theoretical framework for data. Later, when elaborating the life cycle theory with Brumberg, their main concern was not to have a theory consistent with the Keynesian one but with empirical evidence and the connections between micro and macroeconomic analysis. The macroeconomic implications of the life cycle theory were especially developed with Albert Ando in the 1960s as opposed to post-Keynesian theories of economic growth, whereas the life cycle implications for the Keynesian income multiplier were investigated through the Fed-MITPenn large-scale macroeconometric model of the late 1960s (see Chapter 7).

During the 1950s Modigliani was also working on a treatise on the theory of money and interest in a general equilibrium framework, and summarized these ideas in the 1963 article devoted to further develop the Keynesian framework he had set in 1944. However, these notes remained unpublished and were the result of different research lines emerging from an "eclectic" context, as was the Carnegie Institute of Technology of the 1950s (see Chapter 5).

The book provides a broad narrative of Modigliani's approach to economics from the 1940s to the 1970s. It is not comprehensive of all of Modigliani's most innovative and influential achievements, such as his work with Merton Miller on corporate finance, because I consider this as falling outside economics and particularly Keynesian economics. I also do not reconstruct the connections Modigliani established with Italian economists from the mid-1950s, and especially from the late 1960s, when he started to collaborate with the Bank of Italy to build its first macroeconometric model. From then he began to be increasingly involved in the Italian economic and policy situation as well (on this see Asso 2007; Camurri 2010, 2018).

Given Modigliani’s versatility and prominence among Keynesian economists, Modigliani's achievements have been widely investigated. In 1980, Andrew Abel and Simon Johnson started to edit Modigliani's six volumes of Collected Papers (1980-1989), and in 2008 Michael Szenberg and Lall Ramrattan published "Franco Modigliani - Great Thinkers in Economics", a monograph devoted to 
Modigliani's most relevant contributions, for the Macmillan Palgrave series. In 2005, the Italian Accademia Nazionale dei Lincei sponsored a conference, "Franco Modigliani between Economic Theory and Social Commitment", whose proceedings have been published by the Banca Nazionale del Lavoro Quarterly Review. Papers on specific topics of Modigliani's research have also been published.

With few exceptions, such as Harold Hagemann (2005) and, in Italian, Pier Francesco Asso (2007), Renato Camurri (2010, 2018), and Luca Michelini (2019), the abovementioned studies pursued a rational reconstruction of Modigliani's theories focusing on the internal logic of his achievements. Such literature, therefore, may be fruitfully integrated by looking at the historical and intellectual background in which Modigliani's theories originated. The contextualization of his most relevant achievements contributes to a better understanding of the meaning and evolution of his economic thought along with that of modern economics.

My reconstruction of some of Modigliani's main contributions to postwar economics is largely based on the Franco Modigliani Papers preserved the David Rubinstein Rare Book and Manuscript Library of Duke University. Chapter 1, which deals with the articles Modigliani wrote between 1937 and 1938 and published in Italian fascist leading journals, largely benefits of the reading of Luca Michelini's manuscript on Il nazional-fascismo del giovane Modigliani (Michelini 2019), which made me aware of material I did not know about. I am grateful to Michelini for sharing with me his detailed and precious reconstruction of that period.

With the exception of Chapter 1 , the rest of the book is based on results of research presented at conferences and seminars and Chapters 2, 5 and 7 are largely derived from articles already published, integrated with new material. I wish to thank all conference participants and anonymous referees for their helpful comments.

I am especially indebted and grateful to the historians of economics of Duke University whom I first met in 2007, when I began to work on Franco Modigliani papers, and then in 2008 and in 2018, for their continuous support and stimulating suggestions. Without the benefit of the Economists' Papers Project of Duke University (2007, 2008), a research grant from European Society for the History of Economic Thought (2007), the Center for the History of Political Economy fellowship from January to April 2018, and the Fulbright research grant for the 2018 semester, I could not have spent research periods at the Center for the History of Political Economy, which has been fundamental for my work. I also wish to thank the David M. Rubenstein Rare Book and Manuscript Library staff of Duke University for their precious and kind assistance.

\section{Notes}

1 Throughout the book I will use the term neoclassical synthesis and Keynesian economics as interchangeable, and I simply refer to attempts to integrate the neoclassical analysis (in the general equilibrium version) with Keynes's macroeconomics through the IS LM model and to demand policy management.

2 See for example Backhouse (2018) on Samuelson's intellectual biography and Dimand on Tobin (2014). 


\section{Introduction}

\section{References}

Asso, P. F., ed. 2007. Franco Modigliani. L'impegno civile di un'economista, Siena: Fondazione Monte dei Paschi.

Backhouse, R. 2018. Founder of Modern Economics: Paul A. Samuelson: Volume 1: Becoming Samuelson, 1915-1948. Oxford Studies in the History of Economics, Oxford: Oxford University Press.

Barnett, W. A., and R. Solow. 2000. "An Interview with Franco Modigliani November 5-6 1999”, Macroeconomic Dynamics, 4: 222-256.

Blanchard, O. J. 2008. "Neoclassical Synthesis", in The New Palgrave: Dictionary of Economics Second Edition, ed. by S. N. Durlauf and L. E. Blume, vol. 5, London: Macmillan Press Ltd, 634-637.

Camurri, R., ed. 2010. Franco Modigliani. L'Italia vista dall'America. Battaglie e riflessioni di un esule, Turin: Bollati Boringhieri.

— ed. 2018. I modesti consigli di un premio Nobel. Franco Modigliani. Rischio Italia. L'Italia vista dall'America (1970-2003), Rome: Donzelli Editore.

Dimand, Robert, W. 2014. James Tobin, Basingstoke: Palgrave Macmillan.

Hagemann, H. 2005. "The influence of Jacob Marschak, Adolph Lowe, and Hans Neisser on the Formation of Franco Modigliani's work", in Franco Modigliani and the Keynesian Legacy, New York: Schwartz Center Conference at the New School University, April 14-15, 1-25.

Michelini, L. 2019. Il nazionl-fascismo economico del giovane Franco Modigliani, Firenze University. www.academia.edu/40986118/Il_nazional-fascismo_economico_del_giovane_Franco_ Modigliani.

Modigliani, F. 1944. "Liquidity Preference and the Theory of Interest and Money", Econometrica, 12 (January): 45-88.

- 1980-1989. The Collected Papers of Franco Modigliani (5 voll.), ed. by A. Abel, Cambridge, MA: MIT Press.

- 1987. "The 1985 Nobel Prize in Economics", in Macroeconomics and Finance: Essays in Honors of Franco Modigliani, ed. by R. Dornbusch, S. Fisher, and J. Bossons, Cambridge, MA: MIT Press, 29-35.

- 2001. Adventure of an Economist, New York, London: Texere.

Szenberg, M., and L. Ramrattan. 2008. Franco Modigliani a Mind That Never Rests, Palgrave Macmillan. 


\section{References}

1 Also see Camurri (2018) “Tre Nobel dicono no a Berlusconi. Con Paul Samuelson e Robert Solow" (pp. 239-240). The letter was signed also by Henry Rosovsky (emeritus professor at Harvard), Joshua Cohen, and Franklin M. Fisher (emeritus professors at MIT).

2 For a biography of Enrico Modigliani, see Italo Farnetani (2011). Among Enrico Modigliani's initiatives there were the founding in 1918 of the "Opera di assistenza materna - Maternal care institution" that assisted several unmarried mothers and the creation of children's kitchens for free food distribution. He strongly believed that among the main causes of child mortality, which was double for illegitimate children, there was malnutrition (www.treccani.it/enciclopedia/enrico-modigliani. Last access November 6, 2019).

3 Modigliani recalled that at the time (the year 1936) the course in economics he had at the Faculty of Law was about "the theory and institutions of the so-called 'Corporative State', which had nothing to do with modern economic theory" (2001, p. 10).

4 There are some references to Modigliani's writings in Franco Modigliani (Ideological Profile of Economics Laureates): https://econjwatch.org;ModiglianiIPEL.

5 With the promulgation of racial laws, many academic professors lost their positions, as in the case of the economist and statistician Riccardo Bachi, who Modigliani mentioned as his guide in his first readings of economics (see later).

6 For a detailed account of the journals and their editors see Michelini (2019), on which this chapter is largely based.

7 See, for example, Camurri (2018) who refers to Modigliani's attendance at the Centro giovanile per il fascismo universale (Youth Center for Universal Fascism) directed by Ruggero Zangrandi. According to Camurri the center was a sort of "covering structure" for young anti conformists who believed on a universal and anti-imperialist fascism founded on a program of radical economic and social reforms (pp. xxiii-xvi).

8 On the postwar problem-solving approach to economics, see Bernstein (2001), who ascribed it to the use of economics during the war period.

9 On corporative economics and economy in Italy and its lines of thought, see Bini (2017), Guidi (2018) and Barucci et al. ed. (2018).

10 Modigliani also recalled the important support he had from his older cousin Piero Modigliani and about his surprise about the prize. He was than enrolled in his second year at the Faculty of Law.

11 Modigliani also referred to the reading of Benedetto Croce, suggested by his cousin while assisting him in the writing of the piece for the competition, and to Mussolini's support of the Spanish civil war, which was strongly criticized at that time.

12 Part of Modigliani's discussion on price controls is closely related with the devaluation of lira and the risk of a price-wage spiral. Thus, the introduction of price controls was also justified by the need to protect the value of lira and to avoid a redistribution of wealth to the exclusive advantage of those with a variable income.

13 About replacing the concept of homo economicus with "homo corporativus", and the idea of economics as a political and moral science, see, for example, F. Carli (1938), and Gino Arias and Ugo Spirito, on this see Bini (2017). In the 1960s and 1970s Modigliani established close relationships with the son of Filippo Carli, Guido Carli, governor of the Bank of Italy from 1962 to 1972, with which Modigliani collaborated on the building of the bank's macroeconometric model.

14 Modigliani referred to Say's law as having the merit of "supporting the necessary economic solidarity among nations" by recognizing that exports are conditional on the country's imports; thus, economic development of poor countries were desirable (1938, p. 72). He finally emphasized the contradiction of applying to the national and international market behavior a theory based on individual interest because the nation is not the sum of individuals, as social utility is not merely the sum of individual utility. 
15 Modigliani returned to this subject in a short article in March 1938 and then in June. In "Ancora intorno al principio di autarchia" he clarified that autarky is economically advantageous only in the context of the "new economics", which shifts the attention from the individual to the national collectivity, organized in the form of the state, and therefore cannot be extended to the lesser units such as provinces or municipalities. Within a nation could not exist any particular interest, being subordinate to the national ends.

16 Keynes's reasoning was however quite known in Italy at that time and mentioned also within the literature about the corporative economy (see Michelini, 2019, pp. 47-48).

17 As noticed by Michelini (2019, p. 34) in his critique to the liberal egalitarianism, Modigliani appears also inspired by Pareto's and Spencer's Darwinism.

18 Riccardo Bachi was professor of economics at the University of Parma working on methodology and on economic cycles. Mussolini asked him to be involved in the organization of a statistical department for the Ministry of Finance. However, with the promulgation of racial laws, he lost his academic position and moved to Palestine. He came back to Italy in 1946, but he did not return to study economics.

19 See Caffe (1974).

1 The chapter is largely based on Rancan (2017).

Both Ascoli and Contini, along with Bruno Foa, emigrated for racial reasons. Johnson called Ascoli in 1933; see R. J. Tosiello (2000, pp. 107-140); also see Camurri (2012, pp. 166-194).

2 Still, in his interview with Barnett and Solow Modigliani pointed out that "Jasha Marschak was my mentor, we studied Keynes and the GT in classes with Marschak. . . . In addition [I] received a lot of advice and support from him. He suggested me readings and persuaded me of the importance of mathematical tools" (2000, p. 225, see also Breit and Hirsch 2009, p. 118). In his autobiography Modigliani also recalled that "Marschak at once took a liking to me and, first, gave me to understand that if I wanted to get ahead as an economist I should study more mathematics. That was a field I had no grounding - indeed, ever since secondary school I had felt some aversion to it. . . I mugged up books of math and statistics ... [a]ll of which was tremendously useful to me when I tried to develop my articles" (Modigliani 2001, p. 19).

3 Also see Hagemann (2011, p. 659) on Schumpeter's "priority list" about the most prominent European economists.

4 However, according to Mongiovi (2005, p. 431) having experimented with the destructive potential of the state they matured into a less pessimistic view about market mechanisms and embraced more traditional policy interventions with respect to economic planning. Moreover, none of them were any more actively engaged in the policy agenda.

5 Marschak referred to P. Sargant Florence's review of Robinson's book, published in the December 1941 issue.

6 In a letter to Marschak, Modigliani wrote about his relationship with Lerner: "we have been talking much about you with all our common friends, Lange, Loewe and especially Lerner. There seems to be a good deal of understanding between me and Lerner and genuine friendship is gradually developing with him of which I am very happy. I think more and more that Lerner is an exceptionally good economist and I am often amazed at what he manages to do without using calculus. I have the impression that he is very often too extreme in his theories or rather too 'logically extreme' but this very fact makes discussion with him very fruitful because one always knows what one is talking about" (July 16, 1943, MP). See also Barnett and Solow (2000) and Modigliani (2001).

7 See in particular Lerner (1944, Chapter 24), according to which the size of the national debt was relatively unimportant, that the interest on the debt was not a burden on the nation, and that the nation could not be made "bankrupt" by internally held debt. Every 
debt has a corresponding credit. Only external debt is like individual debt and impoverishes a nation. On Lerner see Colander (1980) and de Scitovsky (1984).

8 Modigliani's article was reviewed by Leonid Hurwicz, who at that time was Lange's research assistant at the University of Chicago. From 1942 he was at the Cowles Commission working with Marschak and Koopmans.

9 Solow recalled that "the 1944 article was . . . mostly about Keynes's theory of interest. ... [I]t is interesting then, that the main influence of the paper lay elsewhere" (2005, p. 12).

10 Modigliani concluded the article arguing that under wage flexibility, the long-run equilibrium rate of interest rate is determined by real factors (the classical explanation was still true); under wage rigidity it is determined by the quantity of money and indirectly by savings and investment schedules (1944b, pp. 87-88).

11 Modigliani agreed with Lange's dismissal of Say's law, but he still defended the validity of classical dichotomy. According to him the homogeneity assumption of zero degree of demand and supply functions, which explained such dichotomy, depends on the hypothesis of rationality, that is, no money illusion and not from Say's law.

12 For monetary economy Modigliani meant an economy in which the classical dichotomy breaks down and money is not neutral. He deeply analyzed the validity of classical dichotomy and neutrality of money in the mid-1950s in his long typewritten notes on money (see Chapter 6).

13 However, as Modigliani pointed out in his latest article, "The Keynesian Gospel" (2003), in which he returned to his early Keynesian model: "the difference between rigidity and perfect flexibility turns out to make an enormous difference in the monetary mechanism - the mechanism that ensures the clearing of the money market - and the understanding of unemployment" (2003, p. 3).

14 Modigliani did not explain possible reasons of a fall in the marginal efficiency of investment - whose factors are technological and psychological, such as expectations (1944b, p. 59 fn17). In his handwritten notes on Keynes's General Theory, Chapter 21 ("Incentive to Liquidity"), Modigliani only commented that he agreed with Keynes that "the difficulty of full employment follows "from the association of a conventional and fairly stable long-run rate of interest with a . . . highly unstable marginal efficiency of capital"' (in Keynes - General Theory, Notes and Remarks, MP).

15 In his interview with Barnett and Solow (2000), Modigliani explained that 'Keynes' unique achievement consisted not only in showing that unemployment is the variable that clears the money market; he also elaborated the mechanism by which an excess demand for money causes a decline of output and thus in the demand for money, until the demand matches the given nominal money supply. . . And this starts the chain leading to lower output through a fall in investment, a fall in savings, and thus in income and employment. It is this fall, together with the rise in interest rate, that reduces the demand for money till it matches the supply" (p. 228).

16 Where $\mathrm{M}$ is the money supply, $\mathrm{L}$ the demand for money, $\mathrm{r}$ interest rate and PX money income.

17 Keynes replied to these criticisms acknowledging that their study suggested that there was much to think about and that it had seriously shaken the fundamental assumptions of the short-period theory of distribution. Nonetheless, he pointed out that their conclusions confirmed his idea that the causes of short period fluctuations are to be found in changes in the demand for labor, associated to change in the aggregate demand, rather than in the real wage rate (Keynes 1939, p. 50).

18 Regarding fixed income receivers, because the price level falls, their real income necessarily rises.

19 His analysis on the effects of wage cuts on income distribution was based on data from Census of Manufacturers for the Years 1925-1939 (1944a, p. 77). 
20 Modigliani further developed the theoretical equivalence (not practical, as he remarked) between wage deflation and expansionary monetary policy in the 1955 "Preliminary Notes on Monetary Economics". Subsequent literature on the wage-employment relationship often associates the introduction of the wage rigidity hypothesis as implying the efficacy of wage cuts in restoring full employment. Colander (1996) argued that Keynes's reference to the existence of two opposing schools is less in evidence in the modern literature where "the contrasts take the form - initially prompted by Hansen, Klein, Modigliani and others early proponents of the 'rigid wage version' of Keynesian economics, that the economic system would be self-adjusting if (contrary to experience) wages and prices would adjust rapidly" (Colander, p. 29). See also Leijonhufvud (1968).

21 Apparently Modigliani's (1944b) article initially received little attention from scholars; it was not among the most cited articles published between 1936 and 1948 (ten or more citations in Moggridge 2000, p. 232).

22 Klein's book was an outgrowth of his $\mathrm{PhD}$ dissertation he wrote at MIT under Samuelson's supervision.

23 Regarding Klein's influence on Patinkin, see Patinkin (1956 (1965), p. 234 fn.4), Rubin (2002) and Boianovsky (2006).

24 Because Patinkin's interpretation of Keynes's theory has been largely reconstructed as well as his position in regard to Modigliani's (1944) article, I mainly concentrated on Modigliani's reply to Patinkin's critique. (see De Vroey 2002; Rubin 2002, 2004, 2012; Boianovsky 2002, 2006, among others)

25 Patinkin returned on Lange's and Modigliani's wage rigidity hypothesis in his influential Money Income and Price, rejecting once again their horizontal labor supply on the basis of the inefficacy of wage cuts to restore full employment: "we have shown that reductions in this rate [wage] are neither necessary nor a sufficient condition for the rapid reestablishment of full employment equilibrium" (Patinkin 1956 (1965), pp. 237-238).

26 Luigi Pasinetti, a long-lasting friend of Modigliani and leading post-Keynesian economist, illustrated well this point arguing that in Modigliani, wage rigidity was "a kind of deus ex-machina that solves most of his key problems. . . . Modigliani's method was simplification, which implies concentration on one single point, without bothering about the rest" (2005, pp. 13-15).

27 According to Patinkin "What would be true . . . is that the unemployment disequilibrium would continue for an indefinitely long time. What I mean by unemployment disequilibrium is that the amount of unemployment, the wage rate, and other variables in the system would continuously be changing" (Patinkin to Modigliani: April 7, 1948). Modigliani also explained that in the Keynesian case, the wage rigidity hypothesis is necessary to avoid over-determinacy of the system, "to which you refer on p. 51 of your Cowles Commission manuscript and which you treat at great length in Ch. 6 and 7" (Modigliani to Patinkin: July 2, 1948, MP).

28 Modigliani's and Patinkin's different readings of the wage rigidity assumption also reflected their different approaches to economic analysis. Where there was a choice between rigor and convenience, Modigliani chose the latter, thus he introduced wage rigidity because it "oversimplified the matter" (see, e.g., 1944b, p. 46), whereas Patinkin chose analytical rigor. On different approaches to macroeconomics see Mankiw (2006).

29 In his unpublished reply to Hahn's (1955) critique, Modigliani explained that his model was not stated in general equilibrium language "as it become fashionable since the time of its appearance" (undated, MP). He however admitted he went further in that direction. Modigliani restated explicitly the 1944 model in Walrasian form in 1963 to reply to the so-called Patinkin controversy.

30 In the preface to the Chicago classes (1948-1949), it was stated that Marschak had set himself with the task of synthesizing the old and the new, distilling the best in both, and 
showing how to each set of assumptions corresponds different models with different implications (1951, pp. 3-4). As Lange's and Marschak's influence on Patinkin has been already reconstructed (see Boianovsky 2002, 2006; Rubin 2002, 2012), I only referred to Modigliani. Unfortunately from Modigliani-Marschak correspondence no important elements of Marschak's influence on Modigliani's interpretation of the Keynesian theory emerges; it can be traced only indirectly from Marschak' published works

31 Patinkin introduced the case of absolute wage rigidity "which has special importance for monetary theory" (1956) only in regard to Keynes's interest theory (repeating Modigliani's conclusions), discussing Keynes's unemployment theory separately as a real phenomenon; in Modigliani the unemployment and interest theories are both the result of the monetary mechanism which followed from the wage rigidity hypothesis.

32 During the 1930s Marschak was involved in an active movement, the Kiel-Heidelberg group, against wage-cut policy, which had a leading role in the Weimar debate. According to Marschak a wage cut implied a reallocation of purchasing power from workers to entrepreneurs with negative effects on the demand side: "[s]uch a reallocation of purchasing power naturally is associated with a change in the structural composition of production .... a reallocation of purchasing power in favor of workers, which is associated with higher wages, will stimulate production since the goods consumed by workers are subjected to the law of mass production at higher degree than those goods consumed by the capitalist" (quoted from Hagemann 2005, pp. 16-17).

33 M. Friedman, "The Monetarist Controversy: Discussion by Milton Friedman and Franco Modigliani”, Federal Reserve Bank of San Francisco Economic Review, Supplement, Spring 1977: 5-27.

1 These suggested readings disappeared from the syllabus of the subsequent 1946-1947 academic year. Modigliani also began to teach Statistics with Alfred Kahler.

2 The mechanism of prices formation and the relationships with production factor costs already called Modigliani's attention in the 1930s discussing the advantages of price control, and in his 1939 thesis (see Chapter 1).

3 Modigliani recalled that Burbank "whom I later found out had a reputation of being xenophobic and anti-Semitic - worked very hard and successfully to persuade me to turn down the offer, which the Faculty had instructed him to make me. . . . I have never regretted my decision. . . My career progressed much faster than it would have, if I accepted the offer" (Barnett and Solow 2000, p. 227). In his interview with Camurri Solow provides a partly different explanation arguing that Modigliani was not hired at Harvard because he was not a native English speaker, because he was Keynesian, and because he was a Jew.

4 According to Young et al. (2004) it was Albert Hart who recommended Modigliani to Schultz for a postdoctoral fellowship. In his autobiography Modigliani referred, instead, to Friedman's recommendation; however there is any evidence on it in his Papers.

5 In his reply Singer explained that his request for "a written statement concerning your non-economic background" was part of the appointing procedure at the College which "involves eight or nine different people, and for the shake of the record, some of them who did not know you would have a written statement" (October 20, 1947, MP).

6 In 1947 Marschak again invited Modigliani to join the Cowles Commission as an external consultant, and he accepted.

7 Modigliani replied that if it belonged to him, he certainly would like to have the manuscript returned (November 24, 1947, MP).

8 Modigliani discussed the welfare economics of Hicks (1939) and Lange (1942) and the limits of the Pareto criteria by referring to compensation principle.

9 Also see Daniel B. Klein and Ryan Daza, with Viviana Di Giovinazzo (2013) in https:// econjwatch.org/file_download/750/ModiglianiIPEL.pdf (last accessed November 11, 2019).

10 Modigliani defined imperfect competition in accordance to the standard definition in terms of firms' ability to set prices. He then distinguished between the case of free entry, 
which guarantees only a normal profit but leads to an excessive number of firms with higher production costs.

11 Modigliani recognized that the optimal number and the firms' sizes cannot be closely satisfied either in a private or a socialist economy (1947, p. 467; also see Klein et al. 2013, p. 17).

12 Modigliani played an active role in the income policy debate of the 1970s, especially in Italy (see Rancan 2012).

13 The use of both time series and family budgets data is important as a route Modigliani also pursued in the study of savings in 1947-1949 and with Richard Brumberg to test the life cycle hypothesis on savings. An approach that became lost with the building of macroeconometric models that only concentrated on time series data (see Thomas 1992).

14 Both Marschak and Koopmans informed Modigliani that the atomic physicist Leo Szilard and Gale Johnson had similar ideas. Koopmans also recalled the he proposed a similar plan in 1943 for the distribution of durable consumers' goods during their scarcity (October 8, 1947, MP). Modigliani sent a copy to Michael Kalecki, at that time at the United Nations (October 7, 1947, MP), who was skeptical about its applicability, and to Lerner. He also wrote to the Italian economist Gustavo Del Vecchio because "it could be applied also elsewhere" (October 1947, MP).

15 In a letter on November 21, 1947, Marschak wrote Modigliani that Gale Johnson had undertaken to organize the breakfast meeting, along with Hart and Colm, "and to other people whom you suggest" (November 21, 1947, MP).

16 In his autobiography Modigliani recalled that his interest in savings began in 1946 "because it was held that national savings underpins the availability of capital", and that "saved income growth with income" on the one side, and on the other, there was Keynesian's fear that people might save too much (2001, p. 51).

17 The article was then rejected by Frisch as well. The referee eventually suggested he consider to reducing the article to four to five pages and to submit it as a note (Leavens to Modigliani: February 17, 1947, MP). The managing editor also asked Modigliani to send an abstract for the report of the 1946 meeting in which, however, Modigliani's paper does not appear.

18 Regarding methodology, Modigliani concludes with a section on "Another Method of Estimation", where he relies on Haavelmo $(1943,1944)$ and Koopmans's $(1944,1945)$ new method of estimates, the simultaneous equations method, as alternative to single equation estimates, which became largely applied in the 1950s and 1960s.

19 By secular movement of income Modigliani meant "a movement that carries real income per capita above the highest level reached in any preceding year; by cyclical any movement, whether up or downward, that leaves real income per capita below the highest previous peak" (1947, p. 379).

1 Modigliani replied that if it supposedly belonged to him, he certainly would like to have the manuscript returned (November 24, 1947). The title is mentioned in English, so maybe there was an English translation that was circulating.

2 Margaret Reid was a researcher at Iowa University until 1945 where she was a colleague of Schultz. During 1943-1944 she served as an economic advisor to the Division of Statistical Standards and then she moved to Washington. After her resignation from the University of Illinois (in 1950), she joined the University of Chicago.

Brady moved to the University of Illinois from the U.S. Department of Labor, where she was chief statistician from 1944 to 1948 of the Division of the Bureau of Labor Statistics.

3 Modigliani recalled as follows his acceptance of the offer: "A few months after my arrival at Chicago [having been awarded the prestigious Political Economy Fellowship of the University of Chicago, and to join the Cowles Commission] I was contacted by Howard Bowen, who had just been appointed dean. . . . Bowen asked me to come and work at his University on the project. ... [T] he conditions offered were excellent, 
and the university was prestigious, full of brilliant young economists. I accepted. At the University of Illinois my career went much faster than it could have done at Harvard" (2001, p. 57).

4 There is extensive literature on the effects of the McCarthyism campaign on the development of social science and on economics, particularly about its postwar mathematization, to which I'll return in the next sections.

5 See "The Bowen War" in Franco Modigliani Papers.

6 Modigliani was a research consultant for the Cowles Commission from September 1948 to 1954. The director, Jacob Marschak, was his mentor at the New School for Social Research. Patinkin, who also had Marschak as a supervisor of his $\mathrm{PhD}$ dissertation, attended regularly the Cowles Commission seminars over his period at the University of Chicago (1947-1949); Hurwicz was a research associate for the Cowles Commission as well from 1942 to 1946. Patinkin left the university before the Bowen controversy; therefore, he was not among the distinguished economists who left Illinois in reaction to Bowen's resignation as reported instead in Solberg and Tomilson $(1997$, p. 80).

7 Griffith (1893-1966) was a psychologist who earned his $\mathrm{PhD}$ from the University of Illinois. He was promoted provost in 1944.

8 On the influence of patrons on postwar behavioral sciences, see Hunter CrowtherHeyck (2006).

9 Blodgett was an assistant professor of economics at the University of Illinois since 1937 whose contribution to the discipline mainly consisted of writing textbooks (see Solberg and Tomilson 1997).

10 The letter was signed by V. L. Bassie, D. S. Brady, E. C. Budd, R. Campbell, W. M. Capron, O. C. Herfindhal, L. Hurwicz, G. Kleiner, J. L. McConnell, F. Modigliani, D. W. Paden, M. G. Reid, D. B. Smith, P. N. Vukasin and E. T. Weiler. The letter was also sent to the editor of the News Gazette (in MP).

11 The letter also referred to the charge "specifically made that graduates from California, Chicago, Harvard and Columbia . . . are a selected group who believe in 'Keynesian' and dangerous ideas and could therefore be expected to indoctrinate students with these ideas. These schools are four of the most distinguished in the country - and therefore natural places to recruit able young faculty members. . . [I]t simply happens to be a fact, which could have been ascertained, that the young faculty members in question have various liberal and conservative social and economic viewpoints. ... One other example . . . is the charge that many 'bureaucrats' were brought into the faculty . . . [while] only two appointments were of persons working permanent" (September 16, 1950, MP).

12 Also see Colander and Landreth (1996) and Giraud (2014).

13 Hart also wrote to President Kisselgoff (New York, National Bureau of Economic Research), to Chair Williamson of the board of trustees (Letter from Albert G. Hart to Modigliani, October 19/1950, MP). Letters of support to Bowen were sent to Stoddard by a number of leading economists such as Jean Brofenbrenner and Avram Kisselgoff.

14 In the 1950s, thirty-six faculty members (more than half with tenure) were dismissed for their refusal to sign the loyalty oath as required by the university (see Gardner 1969; Slaughter 1980, p. 58; Schrecker 1986).

15 Scholar victims of McCarthyism, to avoid further complications in achieving new positions, often preferred not to publicize their cases. Nonetheless members of the AEA and ad hoc committees, such as Sharfman, were aware and directly involved in McCarthyism attacks. For example, in March 1955 Sharfman wrote to Gardner to support Klein's recommendation. However tenure was denied, and Klein went to Oxford for almost ten years (see Brazer 1981).

16 According to the committee, Davis's discharge "was not grounded on the fact that he was an economist. There is every reason to believe that the same result would have 
followed if he had been an astronomer. ... The fact that he is an economist, and a member of the AEA, is purely coincidental" (AER 1955, p. 682, n 5). The AAUP published the findings of its investigating committee on Davis only in April 1957 and in December 1957 had not yet disposed the case.

17 In September 1951, Apel, chair of the Economics Department of Bridgeport University, wrote to James Washington Bell (secretary of the AEA) informing him of extramural suggestions to discontinue the use of some textbooks harming the proper education of students. In his reply Bell referred to the AEA's precedent refusal to take a stand on the use of Gemmill's and Blodgett's book (Economic Principles and Problems, 1936) as asked by the Army War Forces Institute's request. Bell explained that the AEA refused to do so "on the grounds that our charter does not permit any officers, representatives, or groups of the Association to speak for its memberships" (Bell to H. Apel: September 19, 1951, American Economic Association Papers). He also referred to the 1947 statement on textbooks and to the Committee on Academic Freedom. No references were made to the attacks suffered by Tarshis's and Samuelson's textbooks.

18 On Lazarsfeld and Thiels (1958) empirical study, see Weintraub's (2016) reading of their material (pp. 24-28).

19 Weintraub (2016) however acknowledged that the widespread professional apprehension and prudence may have discouraged scholars from radical interpretations of Keynes's ideas, thus contributing thanks to the lack of opposition to neoclassical synthesis, of its being dominant at the end of the 1950s.

20 On the shifts from literary to a formalist approach to economics, also see Solow (1997, p. 296).

21 According to Asso (2007, p. 14) it was Salvemini who suggested Modigliani publish his paper on the socialist economy in an Italian journal. But I found no evidence for it. Sylos Labini family was very close with Salvemini and he spent the last months at Harvard (until September 1949) living in the same house. Sylos Labini recalls Modigliani's encounter with Salvemini as follows: "For his part Franco revered Salvemini, and when he came to Harvard from Chicago on a brief visit I introduced them. From then on they kept up regular if not intensive correspondence. Franco was drawn to Salvemini not only on the intellectual plane, but also at the level of political and social commitment" (Sylos Labini 2005).

22 Modigliani and Sylos Labini maintained close correspondence and a lifelong relationship, sharing many intellectual interests. It was Sylos Labini who persuaded Modigliani to return for the first time to Italy in 1954.

On Sylos Labini's and Modigliani’s biographical notes, see Modigliani (2001), Roncaglia (2006) and Sylos Labini (2005).

23 The memorandum is written both in Italian and in English, probably to circulate among non-Italians as well. For example, Salvemini suggested to Modigliani to get in touch with Paul Douglas because he knew Italy well and had similar opinions. He also asked about the availability of Messagerie Italiane (founded and directed by his father-in-law Calabi) for the eventual distribution of the journal.

24 About Modigliani's active involvement since the 1970s onward to the Italian economic and political debate, see in particular Asso's (2007) and Camurri's (2018) publications of Modigliani's journal articles.

1 The chapter is largely based on Rancan (2013).

See NORC Social Research 1941-1964, and F. Modigliani and J. J. Feldman, Expectations and Business Fluctuations: First Progress Report to the Advisory Committee, 1949, 25-26, www.norc.org/PDFs/publications/NORCSocRes_1941_1964.pdf, last access 12 November 2019.

2 See https://academic.oup.com/poq/article/10/3/399/1835002; last accessed November 2019 . 
3 Albert Hart recalled that Bowen consulted him as a possible director of a center for research on the expectational field and that he recommended Modigliani (whom he had placed earlier as a postdoctoral fellow with Schultz at the University of Chicago) (see Young et al. 2004). It was Hart who later recommended Modigliani to Lee Bach (Young et al. 2004).

4 The session was chaired by Colonel Paul D. Guernsey (US Army); the other participants were an anthropologist and a political scientist. Harrod Domar wrote to Modigliani to compliment him on his "first Progress Report on March 1949 regarding your study of 'Expectations and Business Fluctuations'. I think the work you are undertaking is extremely worth-while, to say the least" (May 31, 1949, MP). Modigliani complained to Domar the difficulties he met: "I must confess that the problem is so terribly vast and difficult to come to grasp with, that I frequently feel somewhat discouraged" (June 6, 1949, MP).

5 The use of questionnaires to investigate investment behavior is criticized by Friedman (1949): "I doubt any reasonably simple answers to many of Hart's questions exist; or that if the answer exist, businessmen know them; or that if they do know the answers, they will give them in response to questioning" (p. 199).

6 The interdisciplinary and analytical approach to social sciences was supported over the 1950s by a patronage system formed by public (especially military) and private institutions (foremost the Ford Foundation). Thanks to Simon's involvement in numerous projects and committees, the GSIA represented one of the main beneficiaries, becoming the most important protagonist in the "behavioral revolution".

7 I wish to thank Professor Warren Young for sending me a copy of the document.

8 Merton Miller also won the Nobel Prize in 1990 with Harry R. Markowitz and William F. Sharpe in 1990; see www.nobelprize.org/prizes/economic-sciences/1990/ miller/biographical/.

9 On this interviews see Robert Eisner's (1957) NBER paper on "Interviews and Other Survey Techniques and the Theory of Investment", pp. 513-601.

10 However, in Modigliani there was no reference to the notion of strategy interpreted as a complete plan of actions or as a rule for choosing future actions in response to later information. His focus was on the consequences for the entire "game" of a stepby-step decision rule in which adjustment of later actions to earlier ones represented his crucial point. The same intellectual influence can be found in Simon as well. Regarding Simon's attitude towards game theory, see among others; see also Sent (2001, 2004).

11 See also Modigliani’s autobiography at http://nobelprize.org/nobel_prizes/economics/ laureates/1985/modigliani-autobio.html) and Hartley (2004, p. 433).

12 Modigliani pointed out that the relevance of the "first move" had already been recognized by A. G. Hart (1942, 1951), H. Markowitz (1952), G. Tintner (1941) and Marschak (1949), among others. According to him, however, the plan did not represent a decision as to the actual level of future activity, and it had no implications at all with the respect to future operations: "It seems possible to find many economic instances . . . in which later actions can be adjusted with no loss of efficiency to earlier ones, whatever these might have been, so that these earlier actions may be chosen without regard to later ones" (Modigliani 1952a, p. 20).

13 On the Cowles Commission attitude towards scholars' interchanges, see Düppe and Weintraub (2013). As for the GSIA, Jacque Drèze recalled that "Carnegie in the mid and late fifties was a tremendous place. The permanent staff had constant interchanges. Visitors were entirely welcome. Seminars by outsiders were organized regularly, well attended by the Carnegie Faculty, and the occasion of lively debates. The 'organization of research' looked spontaneous, and graduate students were part of it. Contacts with other departments of the university were not systematic, however, with the exception of 
the notable Charnes-Cooper association. Later on, close ties with statistics developed" (email to the author: September 3, 2009).

14 In a letter to Marschak, Simon pointed out that what he valued "more than anything else in my association with the Cowles Commission has been the opportunities it has provided for interchange of ideas - this has been immensely stimulating to me" and claimed that "the communications lines have been somewhat weak during the past year, although the problems we are jointly working on are closer than ever to my central interests" (June 22, 1953, Simon Collection).

15 Regarding the RAND research project, see Simon (1991) and Mirowski (2002).

16 See Klein (2019).

17 Before accepting the position at the GSIA, Modigliani asked Albert Hart about the possibility of joining him at the Economic Department of Columbia University to carry on his research on expectations, (Hart to Modigliani: March 31, 1952, MP). In a letter dated July 25 1952, Hart was congratulatory about Modigliani's decision to accept the Carnegie offer: "Carnegie Tech . . . is a place where you can strike up constructive relationships with colleagues, and be secure under decent working conditions for a reasonable period. The market will undoubtedly offer you several good spots in the next few years" (July 25, 1952, MP).

18 According to Simon, the production system presented a feedback loop similar to that of a servomechanism (such as a thermostat) by means of which output (actual behavior) is compared with input (the norm) and the difference is fed back into the system to alter the output in the direction of reducing the error (Simon 1955, p. 357). In his autobiography Simon recalled that his father, an engineer, had been a significant contributor to the development of feedback devices, influencing his own approach to the dynamic behavior of economic systems and organizations (Simon, 1991, p. 108).

19 On the other hand, Simon's feedback method first restricted the class of decision rules to those that are dynamically stable then found a rule that was optimal in the sense that it did not depend on forecasts of sales (Simon 1952, p. 7).

20 H. Simon and C. Holt, "The Control of Inventories and Production Rates: A Survey", Journal of the Operations Research Society of America, 2 (3), August 1954. The paper was presented at the Operations Research Conference in Boston, November 1953, and benefited from suggestions by Modigliani and R. Culbertson. According to Simon and Holt, a forecast was good not if the forecast error was small but if the forecast, combined with the decision rule, resulted in low production and inventory costs. It might be that refinement of the forecast beyond a certain point was not terribly important (Simon and Holt 1954, p. 296).

21 "As a matter of fact there is no reason why adjustment and prediction cannot be combined, why the servomechanism cannot encompass both 'feed-back' (or adjustive) and 'feed-forward' (or predictive) control. Indeed, Modigliani and Sauerlender have implicitly recognized this by introducing a feed-forward device in their model of production and inventory behavior (Cooper and Simon 1955, p. 356).

22 The similarity between Simon's and Modigliani's analyses of production planning under uncertainty was stressed both by the editor of the conference proceedings, Mary J. Bowman (1958, p. 7), and A. Hart in his comment on Simon's paper: "For each moves there are several possible responses; for each combination of move-and-response, several moves we may consider making next. As in analyzing chess, we slough off some contingencies as resting on extremely unlikely responses, or as falling into patterns we know from experience we can handle" to conclude that " $[\mathrm{t}]$ his summarizes an underlying theme of much of the paper by Modigliani and Cohen ... and indicates the underlying links between that paper and Simon's analysis" (1955b (1958), p. 7).

23 The realization function established a relation between the actual course of action, the planned course, the anticipated and actual behavior of the environment and certain initial conditions. According to Modigliani and Cohen, once we know the decision $\mathrm{X}_{\mathrm{t}-1}$ 
(t), knowledge of the realization function can replace knowledge of the "very complex" general behavior function (in Modigliani and Cohen 1955b (1958), p. 160). The realization function approach had already been suggested in Modigliani (1952b). Empirical investigations, to derive the realization function, were carried out by Friend and Bronfenbrenner, Eisner, Jean Bronfenbrenner Crockett, Modigliani and Weingartner, and Ferber and Sauerlender.

Modigliani and Cohen also introduced the distinction between parameters that are practically relevant and practically irrelevant taking into account costs and benefits of acquiring information. To analyze whether information is worth acquiring, they refer to Savage's expected utility theory as "the best available tool" for decision making under uncertainty (1955b (1958), pp. 155-156).

24 In his review of the book, Hicks (1963) acknowledged that one of the main results of the study was the distinction between relevant and irrelevant expectations thanks to linear theory. Nonetheless, the recognition that acquiring information is a costly activity and thus decisions may be made without acquiring it still leaves room for the uncertainty problem.

25 When the criterion function is quadratic, the only information required is about the expected values of the variables under consideration (expected sales values) rather than the whole joint probability distribution. On the notion of optimality in the terms of economizing information, see Duarte (2009).

26 As pointed out by Sent (2001), certainty equivalence enabled separation of the optimization problem into two steps: optimization and forecasting. This is the line of reasoning followed by Muth, who first solved the deterministic version of the model and then added uncertainty (pp. 299-300); see also Sheffrin (1996), Lovell (1986) and Lucas and Sargent (1981) among others.

27 In 1958, in a letter to Luigi Pasinetti, Modigliani still showed his enthusiasm for the GSIA's environment: "Coming back to Pittsburgh I have again been impressed by the high quality of the School and by the fervor and passion for research of my old and new colleagues. . . . With the addition of Marschak ... the team is really 'out of this world' and impressively vibrant in respect to the old Harvard composure" (Modigliani to Pasinetti: November 18, 1958, MP, translation by the author).

28 Muth, too, argued that his rational expectations model allowed for both cognitive limits and cognitive biases (2004, in Augier and March ed., 379).

29 Discussing the origin of his paper, Muth denied that it was motivated by the challenge launched by Simon's bounded rationality and recalled: "when Franco Modigliani assigned a problem in class to explain executive salaries. Herbert Simon presented a model to explain that phenomenon. As a member of Modigliani's class, I tried to develop one too, but I wasn't very good" (Young and Darity 2001, p. 783). See also Muth's comments on Grunberg and Modigliani's paper (Young and Darity 2001, p. 788).

30 At the beginning of the 1960s, along with Modigliani Charles Holt, Merton Miller and Lee Bach also left the GSIA. In a letter to Modigliani Miller wrote: "As you can imagine, this has been a very sad week around here [Carnegie Tech], full of the sorrows of parting. Both Charlie and I made our formal announcements of departure this week. Allan Meltzer has also pretty well decided now to take at least a year off. . . . Ed Mansfield going off to Yale for a year and Dick Nelson going to Council in Washington, the economics group is . . going to be pretty well decimated for a while" (April 12, 1961, MP).

31 In his autobiography Modigliani recalled that at the end of 1959, he was invited to be visiting professor at MIT, but the administration at the Carnegie Institute was against it. He also added, "In that period I felt rather annoyed by the university, for I had the impression that the administration did not intend to invest resources in the economics sector. . . . To my dismay, they decided not to replace an excellent economist, Alexander Henderson, who had worked alongside me" (2001, p. 91). Furthermore, in a letter to 
Luigi Pasinetti, Modigliani explained that his decision was motivated by his desire to come back to more traditional researches: "it's been a while I felt the desire of being again part of wider department of economics, more traditional in its interests, and to be more free in the courses to offer and the researches to carry out" (Modigliani to Pasinetti: January 31, 1960, MP, translation by the author). Finally, Drèze recalled that his impression, at the time, was simply "that Modigliani wanted to pursue his career in a department of economics (hopefully MIT) rather than a business school" (September 3, 2010).

32 Muth acknowledged his debt to Modigliani. Modigliani was his teacher of microeconomics, general equilibrium and macroeconomic theory and, partially, statistic, as well as his $\mathrm{PhD}$ dissertation advisor (Sent 2002, p. 292).

33 Emile Grunberg was an Austrian economist who emigrated to the United States during WWII. He was an empirical economist with a Marxian education he had in Germany, where he conducted statistical studies on the progressive proletarization of artisans and small-scale industry. In the United States he especially worked in the field of economic methodology and philosophy of science. In a letter of recommendation for Ernest Manheim for a position in the Economics Department of the University of Kansas City, Gherard Mayer presented Grunberg as follows: "[Grunberg] has overcome his somewhat narrow Marxian bias, is a very able empirical research worker and has improved his theoretical knowledge very considerably by studying here [at the University of Chicago] under [Frank Hyneman] Knight, [Jacob] Viner, [Oskar] Lange, [Paul Howard] Douglas and [John Ulric] Nef" (Gherard E. O. Mayer to Ernest Manheim: August 24 1942; see Brief von Gerhard E. O. Meyer and Ernest Manheim in Kansas City, Mo. Chicago, III., August 24, 1942; translation and comment by Reinhard Mülle: http://agso.unigraz.at/manheim/dt/4_gb/meyer.htm\#8a). Grunberg taught at the University of Akron from 1946 to 1948 and at Carnegie Institute of Technology from 1948 to 1956. He returned to teach at the University of Akron in 1956 until his retirement in 1973.

34 At the same time Simon published a paper on the same topic: "Bandwagon and Underdog Effects and the Possibility of Election Predictions" (1954). Modigliani and Grunberg refer to Simon's suggestion; thus, they were probably still unacquainted with Nash (1950). I wish to thank Nicola Giocoli for drawing my attention to this point.

It is worth noting, however, that Modigliani and Simon were, in the same year, publishing posthumously a paper of a colleague who applied Nash's equilibrium (A. Henderson, The Theory of Duopoly, vol. 68, no 4, Quarterly Journal of Economics). A colleague who, Modigliani recalled in his autobiography, worked alongside him (2001, p. 91).

35 See Christ 1953, "Discussion (Development of Economics Thought)", American Economic Review, 43 (2): 271-274, 1953.

36 I was unable to locate a copy of the paper in the Modigliani papers.

37 Grunberg and Modigliani "Economic Forecasting When the Subject of the Forecast Is Influenced by the Forecast: Comment (to Kemp), 1962".

38 Grunberg's comment to Martin Brofenbenner's manuscript about the 1954 article Grunberg sent to Modigliani; see Grunberg to Modigliani: January 31, 1956, MP.

39 Regarding the debate in the 1930s on the recursive argument, see Giocoli (2003) and Young et al. (2004) among others.

40 M. Bronfenbrenner replaced Modigliani at Carnegie for the 1955 semester, when Modigliani went to visit Italy on a Fulbright grant.

41 The mathematical part of both papers was mainly constructed by Modigliani (see Grunberg and Modigliani correspondence).

42 Modigliani developed the equation system in an appendix sent separately from the letter, which I am unable to locate. 
43 Modigliani also suggested to Grunberg, in revising the paper, to not "change spirit" (April 21, 1959).

44 The paper was part of research carried out in connection with the Columbia University Seminar-Workshop in Expectational Economics, under the direction of Hart. It deals with the effects of correct public forecasting on the stability of the equilibrium using the cobweb and the inventory cycle models as in both cases the conditions for stability around the equilibrium point depend on the foresight of the agents (1961, p. 142).

45 "Furthermore, perfect foresight may have to be defined as perfect foresight of the future time path of the relevant variables and not merely as knowledge of their standing at an arbitrary chosen nearby point of time" (1963, p. 736).

46 Modigliani referred to Holt, Modigliani: "firms' cost structures and the dynamic responses of inventory, production, workforce" in "Inventory Fluctuations and Economic Stabilization, Pt. II", Joint Economic Committee, Washington 1961; on this see Duarte (2009).

47 They refer to the work of Y. Grunfeld and Z. Griliches, "Is Aggregation Necessarily Bad?", Review of Economics and Statistics, 42, 1960: 1-13.

1 Also see Modigliani (2001, pp. 51, 57-59), where he remarked that he and Brumberg were challenging the idea that savings rise with a rise of income and that savings is a luxury good that accumulate in patrimony.

2 Also see Robert Eisner (1956, 1961), who was working on the project.

3 In his reply Modigliani mentioned Christ, Klein, Duesenberry and Brown among people who had already read the paper.

4 Modigliani claimed to have done little to revise the essay, however adding that three of his lectures in Italy had been devoted to that area of work: "Incidentally my lectures on the subject have been very well received - of course not everybody is ready to accept the word but even those that don't are sufficiently stirred up about it to make feel good" (Modigliani to Stroz, May 16 1954, MP).

5 The possibility of carrying out empirical tests was at that time the main problem for the life cycle hypothesis because the lack of data providing joint information on age, assets (net worth) and average expected income; therefore, they were most of the time only indirect. Regarding Reid's tests, Modigliani and Brumberg referred to a communication she provided at a 1952 conference at Minnesota on "Savings, Inflation and Economic Progress", which Modigliani also mentioned in the autobiography. Modigliani recalled that when going back from the conference with Brumberg, they "were rewarded with a ray of light": the role of savings is to accumulate resources to maintain a stable average consumption over the life span (Modigliani 2001, p. 59).

6 On this, also see Modigliani's letter to Sylos Labini in 1956.

7 Modigliani and Brumberg also referred again, as in the1954 article, to the unrecorded comments of Brady, and the contributions of William Hamburger (1951) and James Tobin (1947) in their unpublished $\mathrm{PhD}$ dissertations on consumption and savings at the University of Chicago and at the University of Harvard, respectively. On Tobin's dissertation see Dimand (2014, Chapter 3).

8 Ando and Modigliani had already published in 1957 some tests on the life cycle hypothesis and in 1960 a comparison with Friedman's (1957) theory of permanent income. Important implications of the life cycle hypothesis for macroeconomics referred to the incorporation of finite lifetime models; the consumption and savings life cycle model also played a seminal role for the building of the overlapping generation approach to modeling as in the case of Allais, Samuelson and Dimand (see Barnett and Solow 2000, p. 222).

9 See for example Eisner's (1969) analysis of the weak effect of the 1968 surcharge tax on inflation because it was provisional.

10 As Modigliani wrote to Sylos Labini, they were "a set of notes covering a dozen lessons from my last year classes, which serve as an introduction to a kind of general treatise on 
the theory of money and interest, written partly before the course and partly based on the course itself, and which constitutes the starting point of what I hope will be a book on the subject" (Modigliani to Sylos Labini: September 14, 1956, MP).

11 In an unpublished reply to Hahn's (1955) critique to the "Liquidity Preference" article, Modigliani remarked that his model was not stated in general equilibrium language "as it become fashionable since the time of its appearance", however, recognizing that he went further in that direction (undated, MP).

12 "I must add that the plan to proceed systematically with the analysis of the effect of market forms on employment according to the lines drawn in Rome still exists but I have to continue to postpone it due to other previous commitments. We will come back to talk about it at the right time" (Modigliani to Sylos Labini: September 14, 1956, MP).

13 Apparently Modigliani's discussion of different kinds of money supply was independent from Gurley and Shaw. Commenting Modigliani's early draft of the 1963 article, Patinkin pointed out the similarity between Modigliani's and Gurley and Shaw's distinction and called Modigliani's attention to their volume, which Modigliani then quoted in the 1963 article (Patinkin to Modigliani: May 2, 1962, MP).

14 Modigliani devoted a section to Hicks's (1939) and Mosak's (1944) dynamic general equilibrium analysis and the indeterminacy of price level under unit elasticity of price expectations. According to him, the problem arises because they fixed the interest rate and, therefore, the system became overdetermined: "regardless of the elasticity of expectations if the interest rate (or any other variable) is fixed arbitrary it is of course impossible to clear all markets" (1955, p. 56).

15 Modigliani had spent the first six months of 1955 in Italy, where he discussed at some length with Sylos Labini about market structures and Keynesian unemployment and the role of rigidities (see their correspondence).

16 As showed by Boianovsky and Trautwein (2006), the "prehistory" literature on the relation between the employment level and inflation was extensive in the 1940s and 1950s, pre-announcing the advent and the standard interpretation of the Phillips curve.

1 The chapter is partly based on Rancan (2019).

Modigliani left Carnegie in 1961, moving to Northwestern University with the agreement of joining MIT a year later. At Northwestern University Modigliani taught macroeconomics to Axel Leijonhfvud, who was following him from MIT. Leijonhfvud's influential book on Keynesian economics was partly written as critique to Modigliani's equilibrium approach to Keynes's theory (Backhouse and Boianvosky 2013, Chapter 4).

2 However, according to Mehrling (2014, p. 12), it came too late: the Fed-MIT-Penn model became for a time the new orthodoxy, but the criticism of Tobin and William Brainard (1968) proved decisive, and the alternative framework of Tobin (1969) became the starting point for the next generation of macroeconometric modeling.

3 See "The Monetarist Controversy: Discussion by Milton Friedman and Franco Modigliani”, Federal Reserve Bank of San Francisco Economic Review, Supplement, Spring 1977: $5-27$.

4 Mehrling did not consider the disequilibrium line of thought, which put in dispute the Walrasian market clearing approach and that focused on providing a microfoundation for money market behavior. This line of thought had in Patinkin an important departure point (see Backhouse and Boianovsky 2013).

5 On the analogy of Keynesian economics with engineering, see Mankiw (2006).

6 On the role of ideology in economic analysis and discourse, particularly regarding the debate on inflation and unemployment over the 1970s, see Romani (2018).

7 It was Bach (dean of the newly created GSIA) who asked Modigliani to join him at Carnegie in 1952 to reinforce the study of monetary, mathematical and quantitative economics. They were colleagues until Modigliani moved in 1961 to Northwestern 
University and then MIT. Bach moved to Stanford University in 1963. Since WWII he was a Federal Reserve Board consultant.

8 Similar conclusions were published by Friedman and Meiselman in their report to the Commission on Money and Credit (1963), which initiated the so-called radio station debate with Ando and Modigliani (FM AM debate).

9 See especially Bach (1963) and Minsky (1963). Minsky also complained about neglecting the monetary and financial sectors in postwar macroeconometric models, arguing that it was "a defect that should be corrected" (1963 p. 65-66).

10 In 1963 Modigliani was also working on empirical tests of monetary policy, and of rules versus discretion" aimed at assessing the role of monetary policy in the postwar period, and the feasibility and desirability of replacing discretion with a rule", see Modigliani 1964, 72 (June) issue of the Journal of Political Economy.

11 According to Minsky, the belief that money was important was not inconsistent with the acceptance of the modern income expenditure approach to business cycles (1963). Similarly, according to Bach, Friedman and Schwartz's rediscovery of money and the emerging agreement on portfolio analysis, although through different adjustment mechanisms, could lead to a rapprochement of the monetarists and the Keynesians views (1963, pp. 3-4).

12 Robert Hetzel (2008) in his narrative about the Federal Reserve postwar monetary policy distinguished between the stop-go monetary policy (1965-1979), which had the objective of a low stable unemployment, and the lean against the wind policy (1955-1965; and after 1979), which had the main task of price stability. The stop-go era, on which my narrative focused, is described as the result of the Keynesians' belief that inflation was a real phenomenon and that "fiscal policy and direct intervention by government in price setting should substitute for monetary authority to control inflation and business cycles" (2008, p. 58).

13 Ando, Modigliani and Rasche published the complete list of equations (about 200 equations) only two years after the completion of the model, in 1972 in the American Economic Review (without comments and with reference to the 1969 version). It was followed by two other reports years later, published by the Fed Board in 1985 and 1987 by Brayton and Mauskopf and in 1996 by Brayton and Tinsley. For a brief historical reconstruction of macroeconometric models at the Fed Board, see Brayton et al. (1997).

14 The Fed Board had refused to finance the project for building a large-scale model of the U.S. economy sponsored by the SSRC and submitted to the Board by Lawrence Klein and Duesenberry that resulted in the Brookings model (see Acosta and Pinzón-Fuchs 2018, pp. 11-12). In 1966 Modigliani submitted a research project on the modus operandi of monetary policy to the SSRC. In his memoranda to the Fed Board and the SSRC, Ando partly provided a different reconstruction of the beginning of the collaboration with the Fed Board (see Rancan 2019).

15 None of Modigliani's students involved in the building of the model remained at MIT after 1968: Bischoff moved to the Cowles Commission at Yale (1968-1975), Sutch became an assistant professor at the University of California, de Menil went to Princeton, and from 1970 to 1975 he was the director of the quarterly modeling project of the Ministry of Finance in France. Yaffe also moved to Princeton soon after his PhD.

16 Until the end of 1969 there were two separate econometric models, one at MIT and Penn the other at the Fed Board, and they were merged only at the end of 1970. The reasons were organizational. The two research teams worked mainly separately also due to academia and the Fed Board's different purposes. As Ando explained to Brill, economists from the "academic side" wanted to postpone the work involved in putting together the model and concentrated on improvements of each equation, whereas de Leeuw and Gramlich from the Fed Board "must have a functioning system as soon as possible." Thus, the Fed Board's version had been functioning since November 1967, 
whereas the MIT-Penn version became operational for practical purposes a year later (Ando Report 1969, MP; also see Backhouse and Cherrier 2019).

17 Ando also emphasized the possible use of the econometric model for teaching purposes: "its theoretical structure was somewhat more transparent and easily understood by other economists" so that the model "may provide a better research vehicle for academic economists and a more convenient teaching device in graduate schools" (undated MP).

18 See Modigliani (1944, pp. 75-76); see also Chapter 2. Regarding empirical validation of his monetary view, Modigliani recalled in his autobiography that he was "very happy" to know that Gerard Tinter would have tested empirically his 1944 model.

19 On the FMP model and the debate with monetarists, see Rancan (2019).

20 It was derived from a constant elasticity of substitution (CES) neoclassical production function (see Rasche and Saphiro 1968).

21 According to Hall (1977, p. 90, endnote 25), the putty-clay assumption was proposed for the first time by L. Johansen, "Substitution versus Fixed Production Coefficients in the Theory of Economic Growth: A Synthesis", Econometrica, 27, April 1959. A bibliography of others' contributions are in C. Bliss, "On Putty-Clay", Review of Economic Studies, 35 (68): 105-132. Regarding the FMP model investment function also see Ando, Modigliani, Rasche and Turnovsky (1974).

22 See for example Eisner's (1969) analysis of the weak effect of the 1968 surcharge tax on inflation because it was provisional.

23 On the history of the Phillips curve myth, see Forder (2014).

24 In a 1968 letter for a seminar at Yale, Ando referred to Goldfeld as "my consultant on everything" (February 22, 1968).

25 Modigliani and Sutch's model was developed to test empirically the results of the Kennedy Operation Twist (1961), aimed at reducing the spread between long-term and short-term maturities through the Fed open market and the Treasury debt management operations, to encourage capital inflow.

26 Ando and Modigliani's revised financial sector should have been part of the monograph on the FMP model Ando and Modigliani were preparing.

27 Theoretical differences referred to Ando and Modigliani's dismissal of Brainard and Tobin's (1963) "adding up constraint" because, to them, big corporations followed a satisfying behavior that led them to have residual assets or liabilities in their balance sheets to simplify their decision process. They also replaced Tobin's q, the ratio of the market value of capital assets to their replacement cost, to determine investment. It was substituted with the expected profitability of production activities using new capital. According to Ando and Modigliani, the introduction of the putty-clay assumption made meaningless the concept of reproduction cost if technology and price factors changes. In other words, in the FMP model investment decisions depended on the comparison of the expected rate of return on capital and investment costs (i.e., long-run interest rate). On these differences, also see Ando 1974. On "Tobin's q" theory of investment, see Dimand (2014, Chapter 5).

28 On the FMP model financial sector, see Acosta and Rubin (2019).

29 Since February 1968 Ando began a collaboration with Arnold Zellner with the aim of formalizing "the statistical inference procedure for large scale models including the question of interpreting simulation results" (February 22, $1968 \mathrm{MP}$ ). The problem, Ando explained to Modigliani, was "to develop a more systematic procedure for choosing among alternative specifications of the model" (September 9, 1968 MP). Ando also remarked that the next task was to have a unified model and "to perform extensive diagnostic simulations to understand the characteristics of the model" (September 9, 1968). In April 1968 Daniel Brill wrote to Ando how impressed he was by the "stable full of young horses Zellner has at his command there at Chicago" (April 29, 1968, MP). 
30 The theoretical and practical efforts behind the building of the FMP model (and macroeconometric models in general) also contributed to shape for at least a decade the way of doing macroeconomics by involving a large number of scholars and $\mathrm{PhD}$ students. $\mathrm{On}$ the practice of macroeconomics in connection with macroeconometric model building, see Acosta and Pinzon Fuchs 2019.

31 The battle Modigliani tackled, especially at the Fed Board, and the progressive isolation in which he found himself is evident from the reports of the Fed Board academic consultant meetings of the late 1970s. In the conclusion of the February 1981 meeting, Bach, like "some other consultants, expressed concern that Modigliani wanted to revert to fine tuning" "Summary of Discussion", Academic Consultant Meeting, February 27, 1981, MP). Modigliani was critical about the anti-inflationary policy of the Board and claimed that Fed's independence should be strictly confined to the choice of the most effective monetary policy to accomplish the goals set by the administration of Congress.

32 Modigliani had already criticized the CEA report for 1974 (Modigliani 1974), a copy of which he sent to Fed Chairman Burns and to Robert Holland writing about his concern with the "extremely tight policy" of the last weeks.

33 Still in the 1976 presidential address Modigliani considered empirical evidence inadequate to discriminate between a vertical and nonvertical Phillips curve, particularly because of the asymmetry between upward and downward wage rigidity (Modigliani 1977a; see also Modigliani 1986, p. 79).

34 As for empirical evidence Modigliani argued that in most years from 1957 to 1970, the acceleration of money stock and the acceleration of inflation went against each other and that until 1974 the correlation between changes in inflation and changes in money supply, current and lagged, was about zero, concluding once again, that the only influence of money on prices was indirect through aggregate demand and employment.

35 Most of the audience's attention at the Brookings session (especially of Keynesians like Klein and Tobin) did not concentrate on the introduction of a concept similar or even interchangeable with that of Friedman but on the estimate of NIRU and the feasibility of the policy mix it would support. Modigliani himself, recognized the difficult task he was pursuing in trying to convince the Board: "you feel that I am out of my mind and that a South America style rate of growth of money of 12 or $15 \%$ is totally unacceptable" (Modigliani 1974, MP).

36 Although Holt's theory became especially known through Phelps's 1970 book on microfoundations, Holt began to work on this model already in the 1950s, when he was Modigliani's colleague at Carnegie (see Organization, edited by J. M. March and H. Simon, 1958). Holt's model followed a satisfactory approach to laborers' and firms' decisions making according to which the employee compared the "utility of an alternative state to that of his present state: If the alternative is enough 'better' to outweigh the costs of the transition, the change was made, otherwise not" (Holt 1970, p. 60). Holt's key concept was represented by the adaptive "wage aspiration level", in the sense that it changes as conditions change. This is the "behavioral hypothesis" or "rational research strategy" on which basis the unemployed makes a choice. The initial wage aspiration level is set on the basis of the worker's previous experience (the most recent wage), knowledge of what other workers have achieved, and perceptions of what job opportunities are currently available in the market; and it is inversely related to the unemployed time. In other words, in Holt's search model the rate of change of money wages depends upon the behavior of unemployed and employed workers "in searching the market for their best opportunities" and on "employers' efforts to maintain work forces at their desired levels in the face of quits and recruiting problems" (1970, p. 69).

37 Holt's theory was the only one in Phelps's volume that did not introduce the natural rate hypothesis. 
38 Interesting enough, by applying the standard Phillips curve to Italian data (1952-1968), the coefficient of inflation was already larger than unity. Modigliani and Tarantelli said that this result was already reported by Sylos Labini, in 1967, with no reference to the Phillips curve, who explained it by the increasing of trade union pressure on wages (Modigliani and Tarantelli 1973, p. 210).

39 Modigliani also emphasized the heterogeneity of the labor force in his 1976 presidential address to rationalize price and wage stickiness. According to him in oligopolistic markets, firms respond to changes in demand by endeavoring to adjust output and the employment level without significant changes in prices relative to wages, with effects on vacancies and search time. The rationale behind firms' behavior is that if wages decrease, the first to quit are likely to be the best workers; therefore, a reduction of demand could be accomplished more economically not by reducing wages but by firing or by layoffs (Modigliani 1977a, p. 7).

Barucci, P., P. Bini, and L. Conigliello ed. 2018. Il Corporativismo nell'Italia di Mussolini. Dal declino delle Istituzioni liberali alla Costituzione Repubblicana, Firenze: Firenze University Press.

Bernstein, M. A. 2001. A Perilous Progress, Princeton, NJ: Economists and Public Purpose in Twenty-Century America, University Press.

Bini, P. 2017. "Corporative Economics and the Making of Economic Policy in Italy during the Interwar Years (1922-1940)", in Business Cycles in Economic Though: A History, ed. by A. Alcouffe, M. Poettinger, and B. Schefold, Abingdon, UK: Routledge.

Caffé, F. 1974. "Il tempo nel pensiero di Guglielmo Masci", Il Giornale degli Economisti e Annali di Economia, nuova serie, 33 (9/10), September-October: 679-683.

Camurri, R., ed. 2010. Franco Modigliani. L'Italia vista dall'America. Battaglie e riflessioni di un esule, Turin: Bollati Boringhieri.

—, ed. 2018. I modesti consigli di un premio Nobel. Franco Modigliani. Rischio Italia. L'Italia vista dall'America (1970-2003), Rome: Donzelli Editore.

Carli, F. 1938. Le basi storiche e dottrinario dell'economia coporativa, Padova: Cedam.

Farnetani, I. 2011. "Enrico Modigliani”, Treccani, Dizionario Biografico degli Italiani, 75. www.treccani.it/enciclopedia/enrico-modigliani_(Dizionario-Biografico). Last access November 6, 2019.

Franco Modigliani Papers, David M. Rubenstein Rare Book and Manuscript Library.

Guidi, M. E. L. 2018. Corporate Economics and the Italian Tradition of Economic Thought: A Survey. http://eprints.adm.unipi.it/1275/1/guidi.htm.

Klamer, A. 1984. The New Classical Macroeconomics: Conversations with the New Classical Economists and Their Opponents, Brighton: Harvester Press.

Klein, D. B., R. Daza, and V. D. Giovinazzo. 2013. "Franco Modigliani (Ideological Profile of Economics Laureates)", Econ Journal Watch, 10 (3), September. https://econjwatch. org)ModiglianiIPEL. Last access November 29, 2019.

Markowitz, H. 1952. "Portfolio selection". Journal of Finance, 7: 77-91.

Masci, G. 1934. Saggi critici di metodologia, Catania: Studio Editoriale Moderno.

Michelini, L. 2019. Il nazionl-fascismo economico del giovane Franco Modigliani, Firenze University Press. www.academia.edu/40986118/Il_nazional-fascismo_economico_del_giovane_ Franco_Modigliani.

Modigliani, F. 1937 (2007). Crisi del sistema economico, prezzi politici e autarchia. Cinque articoli giovanili: The Crisis of the Economic System, Political Prices and Autarky: Five Early Works (Roma 1937-1938), ed. by D. Parisi, Vita e Pensiero.

- 1938. "L'autarchia nazionale”, Lo Stato. Rivista di Scienze Politiche, Giuridiche ed Economiche, fascicolo 2: pp. 76-96. 
1939. "La regolamentazione e la standardizzazione dei bilanci, della contabilità e del calcolo del prezzo del costo nei suoi aspetti teorici e nelle sue attuazioni all'estero", Franco Modigliani Papers.

—. 1947. "L'Organizzazione e la Direzione della Produzione in un'Economia Socialista", Giornali degli Economisti e Annali di Economia, 6: 441-514.

. 1985. Franco Modigliani. Biographical, The Sveriges Riksbank Prize in Economic Sciences in Memory of Alfred Nobel 1985 https://www.nobelprize.org/prizes/ economic-sciences/1985/modigliani/biographical/

2001. Adventure of an Economist, Texere.

- Undated. "Plan to Meet the Problem of Rising Meat and Other Food Prices Without Bureaucratic Controls", Franco Modigliani Papers.

Mongiovi, G. 2015. "Franco Modigliani and the Socialist State", Preliminary Draft: 1-22. http://qcpages.qc.cuny.edu/ lussher/mongiovi05.pdfpp. Last access November 29, 2019.

Mosca, M. 2018. Monopoly Power and Competition. The Italian Marginalist Perspective, Cheltenham: Edward Elgar.

Schumpeter, J. A. 1954 (1976). Storia dell'analisi economica, Torino: Bollati Boringhieri.

Backhouse, R. E., and M. Boianovsky. 2013. Transforming Modern Macroeconomics: Exploring Disequilibrium Microfoundations, 1956-2003, Cambridge, NY: Cambridge University Press.

Barnett, W. A., and R. Solow. 2000. "An Interview with Franco Modigliani November 5-6 1999”, Macroeconomic Dynamics, 4: 222-256.

Bodkin, R. G., L. Klein, and K. Marwah. 1991. A History of Macroeconometric model-building, Aldershot: Edward Elgar.

Boianovsky, M. 2002. "Don Patinkin, the Cowles Commission, and the Theory of Unemployment and Aggregate Supply", European Journal of the History of Economic Thought, 9 (2): $226-259$.

- 2006. "The Making of Chapters 13 and 14 of Patinkin's Money, Interest and Prices", History of Political Economy, 38 (2): 193-249.

Breit, W., and B. T. Hirsch, eds. 2009. Lives of the Laureates: Twenty-three Nobel Economists, 5th ed., Cambridge, MA: MIT Press.

Camurri, R. 2010. Franco Modigliani. L'Italia vista dall'America. Battaglie e riflessioni di un esule, Turin: Bollati Boringhieri.

- 2012. "Max Ascoli: un esule non esule", in Max Ascoli. Max Ascoli. Antifascista, intellettuale, giornalista, ed. by Camurri, Franco Angeli, 166-194.

- ed. 2018. I modesti consigli di un premio Nobel. Franco Modigliani. Rischio Italia. L'Italia vista dall'America (1970-2003), Rome: Donzelli Editore.

Cherrier, B. 2010. "Rationalizing Human Organization in an Uncertain World: Jacob Marschak, from Ukrainian Prisons to Behavioral Science Laboratories", History of Political Economy, 42 (3): 443-467.

Christ, C. 1985. "Early Progress in Estimating Quantitative Economic Relationships in America", American Economic Review, 75 (6), 39-52.

Colander, D. 1980. "Post-Keynesian Economics, Abba Lerner and His Critics", Social Research, 47 (2): 352-360. "Lerner's Contributions to Economics", Journal of Economic Literature, 22 (4).

- ed. 1996. Beyond Microfoundations: Post Walrasian Macroeconomics, Cambridge, NY: Cambridge University Press.

de Scitovsky, T. 1984. "Lerner's Contributions to Economics", Journal of Economic Literature, 22 (4): 1547-1571. 
De Vroey, M. 2000. "IS-LM à la Hicks versus IS-LM à la Modigliani”, History of Political Economy, 32 (6): 293-316.

. 2002. "Can Slowly Adjusting Wages Explain Involuntary Unemployment? A Critical Re-examination of Patinkin's Theory of Involuntary Unemployment", European Journal of the History of Economic Thought, 9 (2): 293-307.

Dimand, R., and H. Hagemann. 2019. "Jacob Marschak and the Cowles Approaches to the Theory of Money and Assets", Cowles Foundation Discussion Paper no 2196. www. researchgate.net/publication/335677051. Last access November 29, 2019.

Düppe, T., and E. R. Weintraub. 2013. "Siting the New Economic Science: The Cowles Commission's Activity Analysis Conference of June 1949”, Science in Context, 27 (3): 453-483.

Friedman, M. 1977. "The Monetarist Controversy: Discussion by Milton Friedman and Franco Modigliani”, Federal Reserve Bank of San Francisco Economic Review, Supplement, Spring: 5-27.

Haberler, G. 1946. "The Place of the General Theory of Employment, Interest, and Money in the History of Economic Thought", The Review of Economics and Statistics, 28 (4), November: 187-194.

- 2005. The Influence of Jacob Marschak, Adolph Lowe, and Hans Neisser on the Formation of Franco Modigliani's Work, Franco Modigliani and the Keynesian Legacy, Schwartz Center Conference at the New School University, New York, April 14-15: 1-25.

- 2011. "European émigrés and the 'Americanization' of Economics", The European Journal of the History of Economic Thought, 18 (5): 643-671.

Hansen, A. H. 1946. "Keynes and the General Theory", The Review of Economics and Statistics, 28 (4), 182-187.

-1949. Monetary Theory and Fiscal Policy, New York: McGraw-Hill Book Co.

Hicks, J. R. 1937. “Mr. Keynes and the 'Classics': A Suggested Interpretation”, Econometrica, 5 (2): $147-159$.

Klamer, A. 1984. The New Classical Macroeconomics: Conversations with the New Classical Economists and Their Opponents, Brighton: Harvester Press.

Klein, L. 1947 (1966). The Keynesian Revolution, 2nd ed., New York: McMillan.

Koopmans, T. 1978. "Jacob Marschak, 1898-1977”, American Economic Review, 68 (2): ix-xi.

Lange, O. 1938. "The Rate of Interest and the Optimum Propensity to Consume, the Rate of Interest and the Optimum Propensity to Consume", Economica, New Series, 5 (17): 12-32.

- 1944. Price Flexibility and Employment, Cowles Commission for Research in Economics, Monograph No 8.

Lederer, E. 1936. "Commentary on Keynes. II”, Social Research, 3 (4): 478-487.

Leijonhufvud, A. 1968. On Keynesian Economics and the Economics of Keynes: A Study in Monetary Theory, New York: Oxford University Press.

Leontief, W. 1936. "The Fundamental Assumption of Mr. Keynes's Monetary Theory of Unemployment”, Quarterly Journal of Economics, 51 (1), November: 192-197.

Lerner, A. 1939. "The Relation of Wage Policies and Prices Policies", American Economic Review, 29 (1), Supplement: 158-169.

- 1944. "Interest Theory: Supply and Demand for Loans or Supply and Demand for Cash", The Review of Economics and Statistics, 26 (2): 88-91.

Mankiw, N. G. 2006. "The Macroeconomist as Scientist and Engineer”, The Journal of Economic Perspective, 20 (4), Fall: 29-46.

Marschak, J. 1943. "Money Illusion and Demand Analysis", Review of Economics and Statistics, 25: 40-48. 
1951. Income, Employment and the Price Level: Notes of Lectures Given at the University of Chicago in Autumn 1948 and 1949, ed. by D. I. Fand and H. Markowitz, New York: Augustus M. Kelley, Kelley Reprints of Economic Classics, 1965; Cowles Commission Discussion Paper no. 250, 1949 (as 20 Lectures on Income, Employment and the Price Level).

Mehrling, P. 2002. "Don Patinkin and the Origin of Postwar Monetary Orthodoxy", European Journal of Economic Thought, 9: 161-185.

- 2010. "A Tale of Two Cities", History of Political Economy, 42: 201-219.

Franco Modigliani Papers, David M. Rubenstein Rare Book and Manuscript Library, Duke University.

Modigliani, F. 1944a. The General Theory of Employment, Interest and Money under the Assumptions of Flexible Prices and of Fixed Prices, Thesis, Doctorate for Social Science.

- 1944b. "Liquidity Preference and the Theory of Interest and Money", Econometrica, 12, January: 45-88.

- 1955. "Theory of Money and Interest in the Framework of the General Equilibrium Analysis", Preliminary Notes, Modigliani Papers.

- 1963. "The Monetary Mechanism and Its Interaction with Real Phenomena", The Review of Economics and Statistics, 45 (1), Part 2, Supplement, February: 79-107.

- 2001. Adventure of an Economist, New York and London: Texere. $3-47$.

Moggridge, D. E. 2000. "The Diffusion of the Keynesian Revolution: The Young and the Graduate Schools", in History of Political Economy, Supplement, 223-241.

Mongiovi, G. 2005. "Emigré Economists and American Neoclassical Economics", Journal of the History of Economic Thought, 27 (4): 427-437.

Neisser, H. 1936. "Commentary on Keynes”, Social Research, 3 (4): 459-478.

. 2015. "Franco Modigliani and the Socialist State", Preliminary Draft: 1-22. http:// qcpages.qc.cuny.edu/ lussher/mongiovi05.pdfpp. Last access November 2019.

Pasinetti, L. L. 2005. How Much of J. M. Keynes Can We Find in Franco Modigliani, in Franco Modigliani between Economic Theory and Social Commitment, Proceeding of the International Conference Organized by the Accademia Nazionale dei Lincei, Roma, February 17-18, Banca Nazionale del Lavoro, Quarterly Review, 58: 21-40.

Patinkin, D. 1948. “Correspondence with Franco Modigliani”, Patinkin Papers, Box 29.

- 1956 (1965). Money Interests and Prices: An Integration of Monetary and Value Theory, 2nd ed., New York: Harper \& Row.

Rancan, A. 2017. “The Wage-Employment Relationship in Modigliani’s 1944 article", European Journal of the History of Economic Thought 24 (1): 143-174.

Rubin, G. 2002. "From Equilibrium to Disequilibrium: The Genesis of Don Patinkin's Interpretation of the Keynesian Theory", European Journal of the History of Economic Thought, 9 (2): 205-225.

- 2004. "Patinkin on IS-LM: An Alternative to Modigliani", in The IS-LM Model: Its Rise, Fall, and Strange Persistence: History of Political Economy, ed. by M. De Vroey and K. D. Hoover, 36 Supplement: 90-216.

- 2012. "Don Patinkin's, PhD Dissertation as the Prehistory of Disequilibrium Theories", History of Political Economy, 44 (2): 235-276.

Samuelson, P. A. 1948. Economics: An Introductory Analysis, New York: McGraw-Hill Book Co. 
1987. "The 1985 Nobel Prize in Economics", in Macroeconomics and Finance: Essays in Honors of Franco Modigliani, ed. by R. Dornbusch, S. Fisher, and J. Bossons, Cambridge, MA: MIT Press, 29-35.

- 2005. Franco: A Mind Never at Rest, Franco Modigliani between Economic Theory and Social Commitment, Proceeding of the International Conference Organized by the Accademia Nazionale dei Lincei, Roma, February 17-18, Banca Nazionale del Lavoro, Quarterly Review, 58: 5-10.

Schumpeter, A. J. 1946. "The General Theory of Employment, Interest and Money by John Maynard Keynes”, Journal of the American Statistical Association, 31 (196): 791-795.

_. 1946. "John Maynard Keynes 1883-1946”, American Economic Review, 36 (4): 495-518.

Solow, R. 2005. "Modigliani and Keynes", Franco Modigliani between Economic Theory and Social Commitment, Proceeding of the International Conference Organized by the Accademia Nazionale dei Lincei, Roma, February 17-18, Banca Nazionale del Lavoro, Quarterly Review, 58: 11-20.

Tarshis, L. 1939. "Changes in Real and Money Wages”, The Economic Journal, 49 (193): 150-154.

Tobin, J. 1958. "Liquidity Preference as Behavior Towards Risk", Review of Economic Studies, 25: 65-86.

Tosiello, J. R. 2000. "Max Ascoli: A Lifetime of Rockfeller Connections", in The "Unacceptables": American Foundations and Refugees Scholars between the Two Wars and after, ed. by G. Gemelli, Bruxel: Lang, 107-140.

Alacevich, M., P. F. Asso, and S. Nerozzi. 2015. "The Shaping of Public Economic Discourse in Postwar America: The 1947 Meat Shortage and Franco Modigliani's Meat Plan", Research in History of Economic Thought and Methodology, 33 (1): 1-46.

Asso P. F., ed. 2007. Franco Modigliani. L'impegno civile di un'economista, Siena: Fondazione Monte dei Paschi.

Barnett, W. A., and R. Solow. 2000. "An Interview with Franco Modigliani November 5-1999”, Macroeconomic Dynamics, 4: 222-256.

Brady, D., and R. D. Friedman. 1947. "Savings and the Income Distribution", Studies in Income and Wealth, National Bureau of Economic Research, 247-265.

Brown, T. M. 1952. "Habit Persistence and Lags in Consumer Behavior", Econometrica, 20 (July): 355-371.

Duesenberry, J. S. 1949. Income, Saving and the Theory of Consumer Behavior, Cambridge, MA: Harvard University Press.

Dunlop, J. T. 1938. "The movement of real and money wages". The Economic Journal, 48 (191), 413-433.

Goodwin, C. D. 1998. "The Patrons of Economics in a Time of Transformation, From Interwar Pluralism to Postwar Neoclassicism: American Economics: The Character of Transformation, ed. by M. M. Morgan and M. Rutherford", History of Political Economy, 30 (Issue Supplement): 53-81.

Haavelmo, T. 1943. "The Statistical Implications of a System of Simultaneous Equations", Econometrica, 11 (1): 1-12.

- 1944. "The Probability Approach in Econometrics", Econometrica, 12 Supplement (July): 1-118.

Haberler, G. 1937. Prosperity and Depression: A Theoretical Analysis of Cyclical Movements, League of Nations.

Hicks, J. 1939. "The Foundations of Economics of Welfare”, Economic Journal, 49: 696-712.

Kalecki, M. 1938. "The determinants of distribution of the national income". Econometrica, $6(2): 97-112$. 
Keynes, J.M. 1939. "Relative movements of real wages and output". Economic journal, 49 (193): 34-51.

Klein, D. B., R. Daza, and V. D. Giovinazzo. 2013. "Franco Modigliani (Ideological Profile of Economics Laureates)", Econ Journal Watch, 10 (3), September. https://econjwatch. org)ModiglianiIPEL.

Kuznets, S. 1946. National Income a Summary of Findings, National Bureau of Economic Research, New York: Arno Press.

Lange, O. 1936. "On the Economic Theory of Socialism, Part One”, Review of Economic Studies, 4: 53-71.

- 1937. "On the Economic Theory of Socialism. Part Two", Review of Economic Studies, 4: 123-142.

- 1942. "The Foundations of Welfare Economics", Econometrica, 10 (3): 215-228.

Lerner, A. P. 1937. "Statics and Dynamics in Socialist Economics", Economic Journal, 47 (186): 253-270.

- 1944. Economics of Control, Oxford: Oxford University Press.

Modigliani (Franco) Papers. David M. Rubenstein Rare Book and Manuscript Library, Duke University.

Modigliani, F. 1937. "Concetti generali sul controllo dei prezzi”, Lo Stato. Rivista di Scienze Politiche, Giuridiche ed Economiche (Aprile): 220-232.

- 1944. "Liquidity Preference and the Theory of Interest and Money", Econometrica, 12 (January): 45-88.

- 1947. "L'Organizzazione e la Direzione della Produzione in un'Economia Socialista", Giornali degli Economisti e Annali di Economia, 6, 441-514.

- 1949. "Fluctuations in the Saving-Income Ratio: A Problem in Economic Forecasting", Studies in Income and Wealth, New York: National Bureau of Economic Research, no. 11, 371-441.

- 1975. "The Life-Cycle Hypothesis of Savings Twenty Years Later" Contemporary Issues in Economics, ed. by M. Parkin and A. R. Nobay. Manchester: Manchester University Press.

- 1980-1989. The Collected Papers of Franco Modigliani (voll. 5), ed. by A. Abel, Cambridge, MA: MIT Press.

- 1986. "Life Cycle, Individual Thrift, and the Wealth of Nations", American Economic Review, 76 (3): 297-313.

- 2001. Adventure of an Economist, New York and London: Texere.

- Undated. "Plan to Meet the Problem of Rising Meat and Other Food Prices Without Bureaucratic Controls", Franco Modigliani Papers.

Modigliani, F., and R. Brumberg. 1953. "Utility Analysis and Aggregate Consumption Functions: An Attempt at Integrating”, Franco Modigliani Papers); Box RW 43, David M. Rubenstein Rare Book and Manuscript, Duke University.

Mongiovi, G. 2005. "Emigré Economists and American Neoclassical Economics", Journal of the History of Economic Thought, 27 (4): 427-437.

- 2015. "Franco Modigliani and the Socialist State", Preliminary Draft: 1-22. http:// qcpages.qc.cuny.edu/ lussher/mongiovi05.pdfpp. Last access November 29, 2019.

Mosak, J. L. 1945. "Forecasting Postwar Demand III”, Econometrica, 13 (1): 25-53.

Neisser, H., and F. Modigliani. 1946. "Cyclical and Secular Factors in the Relationships between Income, Consumption and Savings", U.S. Department of Commerce Bulletin.

- 1953. National Incomes and International Trade: A Quantitative Analysis, Urbana: University of Illinois Press, xviii-396. 
Rancan, A. 2012. "Politica dei redditi e spesa pubblica nella visione di Franco Modigliani”, in Saggi di Economia Pubblica, Jovene Editore.

Schrecker, E. W. 1986. No Ivory Tower: McCarthyism \& the Universities, Oxford: Oxford University Press.

Smithies, A. 1945. "Forecasting Postwar Demand I", Econometrica, 13 (1): 1-14.

Szenberg, M., and L. Ramrattan. 2008. Franco Modigliani a Mind That Never Rests, Palgrave Macmillan.

Thomas J. J. 1992. "Income Distribution and the Estimation of the Consumption Function: A Historical Analysis of the Early Arguments". In History of Political Economy, 24 (1): 153-181.

Tinbergen, J. 1939. Business Cycles in the United States, 1919-1932 Statistical Testing of Business Cycles Theory, vol. 2, Geneva: League of Nations.

Trautwein, H.-M. 2017. "Some International Aspects of Business Cycles: Neisser, Haberler, and Modern Open Economy Macroeconomics", Journal of the History of Economic Thought, 39 (Special issue 1) Business Cycles and Economic Growth: 47-67.

Woytinsky, W. S. 1946. "Relationships between Consumers' Expenditures, Savings, and Disposable Income", Review of Economic Statistics, 28 (21): 1-12.

Young, W., R. Leeson, and W. Darity, Jr. 2004. Economics, Economists, and Expectations: Microfoundations to Macroapplications, New York: Routledge.

American Economic Association Papers, David M. Rubenstein Rare Book and Manuscript Library, Duke University.

American Economic Association. 1950. "Report of the Secretary for the Year 1949", The American Economic Review, 40 (2): 588-602.

Asso, P. F. 2007. Franco Modigliani. L'impegno civile di un'economista, Siena: Fondazione Monte dei Paschi.

Backhouse, R. 2006. "Economics since the Second World War". http://www.lse.ac.uk/ CPNSS/events/Abstracts/HIstoryofPoswarScience/Econsince1945.pdf.

Bahr, H. M. 1967. "Violation of Academic Freedom: Official Statistics and Personal Reports", Social Problems, 14 (3): 310-320.

Bell, D. 1982. The Social Sciences since the Second World War, New Brunswick, NJ: Transaction Books.

Bernstein, M. A. 2001. A Perilous Progress: Economists and Public Purpose in Twenty-Century America, Princeton: Princeton University Press.

Bowen, H. 1988. Academic Recollection, Washington, DC: American Association for Higher Educational.

Brazer, M. C. 1981. "The Economics Department of the University of Michigan: A Centennial Retrospective", in Economics and the World Around It, ed. by S. H. Hymans, Ann Arbor, MI: The University of Michigan Press, 133-275.

Byrd, L. J. 1972. "The Role of Keynesians in Wartime Policy and Postwar Planning, 19401946”, AER, 62 (1-2), 125-133.

Camurri, R. 2018. Franco Modigliani. Rischio Italia. L'economia italiana vista dall'America (1970-2003). Rome: Donzelli Editore.

Coats, A. W. 1960. "The First Two Decades of the American Economic Association", American Economic Review, 50 (4): 556-574.

Coats, B. 1985. "The American Economic Association", Journal of Economic Literature, XXIII, December.

Colander, D. C., and H. Landreth, eds. 1996. The Coming of Keynesianism to America: Conversations with the Founders of Keynesian Economics. Brookfield, VT: Edward Elgar. 
Don Patinkin Papers, David M. Rubenstein Rare Book and Manuscript Library, Duke University.

Galbraith, J. K. 1998. "How Keynes Came to America, in Keynesianism and the Keynesian Revolution in America", in A Memorial Volume in Honour of Lorie Tarshis, ed. by O. F. Hamouda and B. B. Price, Cheltenham: Edward Elgar.

Gardner, D. P. 1969. "By Oath and Association: The California Folly", The Journal of Higher Education, 40 (2): 122-134.

Giraud, Y. 2014. "Negotiating 'the Middle-of-the-Road' Position: Paul Samuelson, the MIT, and the Politics of Textbook Writing 1945-55", in MIT and the Transformation of American Economics, ed. by E. R. Weintraub, Durham, NC, Duke University Press, 134-152.

Goodwin, C. D. 1998. "The Patrons of Economics in a Time of Transformation," in From Interwar Pluralism to Postwar Neoclassicism. American Economics: The Character of Transformation, ed. Mary M. Morgan and M. Rutherford", History of Political Economy 30 (Supplement): 53-81.

Hunter, C.-H. 2006. Patrons of the Revolution. Ideals and Institutions in Postwar Behavioral Science, Chicago: University of Chicago Press.

Lazarsfeld, P. F., and W. Thielens, Jr. 1958. The Academic Mind: Social Scientists in a Time of Crisis, Glencoe IL: Free Press.

Machlup, F., H. Bowen, and R. B. Heflebower. 1958. "Report of the Committee on Academic Freedom and Civil Liberties", American Economic Review, 48 (2): 651-653.

Modigliani (Franco) Papers, David M. Rubenstein Rare Book and Manuscript Library, Duke University.

Modigliani, F. 1947. "L'Organizzazione e la Direzione della Produzione in un' Economia Socialista", Giornali degli Economisti e Annali di Economia, 6: 441-514. .1980-1989. The Collected Papers of Franco Modigliani (voll. 5), ed. by Andrew Abel, Cambridge, MA: MIT Press.

- 2001. Adventure of an Economist, New York: Texere.

Mongiovi, G. 2015. "Franco Modigliani and the Socialist State", Preliminary Draft: 1-22. http://qcpages.qc.cuny.edu/ lussher/mongiovi05.pdfpp. Last access November 29, 2019.

Morgan, M. S., and M. Rutherford, eds. 1998. "From Interwar Pluralism to Postwar Neoclassicism. American Economics: The Character of Transformation", History of Political Economy, 30 (Supplement): 53-81.

Roncaglia, A. 2006. "Paolo Sylos Labini, 1920-2005", Moneta e Credito, 59 (233): 4-21.

Schrecker, E. W. 1986. No Ivory Tower. McCarthyism \& The Universities, New York: Oxford University Press.

Sharfman, I. L., and B. W. Lewis. 1955. "Report of the Exploratory Committee on the Status of the Profession", The American Economic Review, 45 (2): 677-684.

Slaughter, S. 1980. "The Danger Zone: Academic Freedom and Civil Liberties", Annals of the American Academy of Political and Social Science, March: 46-61.

Solberg W. U., and R. W. Tomilson. 1997. "Academic McCarthyism and Keynesian Economics: The Bowen Controversy at the University of Illinois", History of Political Economy, 29 (1): 55-81.

Solow, R., 1997. "How did Economics Get That Way and What Way Did It Get?", Deadalus, 126 (1), American Academic Culture in Transformation: Fifty Years, Four Disciplines (Winter), 39-58.

Sylos Labini, P. 2005. "Franco Modigliani and Oligopoly", Banca Nazionale del Lavoro Quarterly Review, 58 (233-234): 41-48. 
Tarshis, L. 1947. The Elements of Economics: An Introduction to the Theory of Price and Employment, Boston: Houghton Mifflin Company.

Weintraub, E. R. 2002. How Economics Became a Mathematical Science. Durham, NC: Duke University Press.

—. 2014. "Mit's Openness to Jewish Economists" History of Political Economy, 46 (suppl. 1): 45-59.

- 2016. "McCarthyism and the Mathematization of Economics", The Center for the History of Political Economy Working Paper Series 2016-18. Available at SSRN: https://ssrn.com/abstract=2736936 or http://dx.doi.org/10.2139/ssrn.2736936.

Wilcox, C., M. Newcomer, and P. M. O'Leary. 1954. "Report of the Ad Hoc Committee on Freedom of Teaching", The American Economic Review, 44 (2): 733-737.

Augier, M., and G. March. Models of Man: Essays in Memory of Herbert A. Simon, Carnegie, MA: MIT Press.

Bosson, J., and F. Modigliani. 1960. "The Source of Regressiveness in Surveys of Businessmen's Short-Run Expectations", in The Quality and Economic Significance of Anticipation Data, ed. by A. Hart, G. H. Orcutt, and F. Modigliani, Princeton, NJ: NBER and Princeton University Press, 239-263.

- 1963. "On the Reasonableness of Regressive Expectations”, MIT's Library, (10-63), March 11: 1-73, mimeo.

1966. "Statistical vs. Structural Explanations of Understatement and Regressivity in 'Rational Expectations"', Econometrica, 34 (2): 347-353.

Bowman, M., ed. 1958. Expectations, Uncertainty, and Business Behavior, a Conference Held at CIT, 20-27 October, 1955, under the Auspices of the Committee on Business Enterprise Research, New York: SSRC.

Cherrier, B. 2010. "Rationalizing Human Organization in an Uncertain World: Jacob Marschak from Ukrainian Prisons to Behavioral Science Laboratories", History of Political Economy, 42 (3): 443-467.

Cooper, W. W., and H. A. Simon. 1955. "Comment on Modigliani and Sauerlender" ShortTerm Economic Forecasting. Studies in Income and Wealth, vol. 17, Princeton: Princeton University Press, 352-359.

Crowther-Heyck, H. 2006. "Herbert Simon and the GSIA: Building an Interdisciplinary Community", Journal of the History of the Behavioral Science, 42 (4), Fall: 311-334.

Devletoglou, E. A. 1961. "Correct Public Prediction and the Stability of Equilibrium", Journal of Political Economy, 69, April: 142-169.

Duarte, P. G. 2009. "A Feasible and Objective Concept of Optimality: The Quadratic Loss Function and U.S. Monetary Policy in the 1960s and the 1970s", History of Political Economy, (suppl. 1), 41: 1-55.

Düppe, T., and E. R. Weintraub. 2013. "Siting the New Economic Science: The Cowles Commission's Activity Analysis Conference of June 1949”, Science in Context, 27 (3): 453-483.

Eisner, R. 1957. "Interviews and Other Survey Techniques and the Theory of Investment", National Bureau of Economic Research: 513-601.

Friedman, M. 1949. “Discussion.” American Economic Review 39 (3): 196-199.

Giocoli, N. 2003. Modeling Rational Agents: From Interwar Economics to Early Modern Game Theory, Cheltenham, UK and Northampton, MA, USA: Edward Elgar.

Grunberg, E., and F. Modigliani. 1954. "The Predictability of Social Events", Journal of Political Economy, 62 (6): 465-478.

- 1963. "Economic Forecasting When the Subject of the Forecast Is Influenced by the Forecast: Comment to Kemp 1962", American Economic Review: 734-736. 
Grunfeld, Y., and Z. Griliches. 1960. "Is Aggregation Necessarily Bad?”, Review of Economics and Statistics, 42: 1-13.

Hart, A. G. 1942. "Risk, Uncertainty and the Unpredictability of Compounding Probabilities", Studies in Mathematical Economics and Econometrics in Memory of Henry Schultz, ed. by H. Schultz, O. Lange, F. Mcintyre, and T. O. Yntema, Chicago: University of Chicago Press.

- 1949. "Assets, Liquidity and Investment", American Economic Review, 39 (3): 171-181.

- 1951. Anticipations, Uncertainty and Dynamic Planning, New York: M. Kelley, August. Hartley, J. E. 2004. "Modigliani's Expectations”, Eastern Economic Journal, 30 (3): 427-440.

Hicks, J. 1939. Value and Capital: An Inquiry into the Fundamental Principles of Economic Theory, Oxford: Clarendon Press.

- 1963. "Reviewed Work: The Role of Anticipations and Plans in Economic Behaviour and Their Use in Economic Analysis and Forecasting by F. Modigliani; K. J. Cohen", Economic Journal, 73 (289): 99-101.

Holt C. C. 2004. "Rational Forecasting, Learning, and Decision Making" in Models of Man. Essays in memory of Herbert H. Simon: 355-364.

Holt, C. C., and F. Modigliani. 1960. "Firms' Cost Structures and the Dynamic Responses of Inventory, Production, Workforce", Inventory Fluctuations and Economic Stabilization, Pt. II, Joint Economic Committee, Washington.

Holt, C. C., F. Modigliani, and J. F. Muth. 1956. "Derivation of a Linear Decision Rule for Production and Employment", Management Science, 2 (2): 159-177.

Holt, C. C., F. Modigliani, J. F. Muth, and H. Simon. 1961. Planning Production, Inventories and Work Forces, Prentice-Hall.

Holt, C. C., F. Modigliani, and H. Simon. 1955. "A Linear Decision Rule for Production and Employment Scheduling”, ONR Research Memorandum no. 30, May, 1-53.

Klamer, A. 1983. The New Classical Macroeconomics: Conversations with the New Classical Economists and Their Opponents, Harvester Press.

Klein, J. 2019. "The Cold War Hot House for Modeling Strategies at the Carnegie Institute of Technology", Working Paper No 19, Institute for New Economic Thinking, 1-69.

Knight, F. H. 1947. Freedom and Reform: Essays in Economics and Social Philosophy. New York: Harper.

Levin, H. J. 1958. "Public Prediction in Theory and Facts", Southern Economic Journal 24 (3): $338-352$.

Lovell, M. C. 1986. "Tests of the Rational Expectations Hypothesis", American Economic Review, 76 (1): 110-124.

Lucas, R. E., Jr., and T. Sargent. 1981. Rational Expectations and Econometric Practice, vol. 1, Minneapolis: University of Minnesota Press.

Markowitz, H. M. 1950. "On the Certainty Equivalence and Risk Discount Hypothesis", Cowles Commission Discussion Papers Economics. https://cowles.yale.edu/sites/default/files/ files/pub/cdp/e-0295.pdf.

Marschak, J. 1949. "Role of Liquidity Under Complete and Incomplete Information", American Economic Review, 39 (3): 182-195.

Modigliani (Franco) Papers, David M. Rubenstein Rare Book and Manuscript Library, Duke University.

Mirowski, P. 2002. Machine Dreams, Cambridge: Cambridge University Press.

Modigliani, F. 1949a. "Discussion", American Economic Review, 39 (3): 201-208.

- 1949b. "New Areas of Opinion Research: in other social sciences", Public Opinion Quarterly, 13 (4): 770-771.

_. 1952a. "Some Considerations on the Expectations and Planning Horizon Relevant to Entrepreneurial Decisions”, Cowles Commission Paper, Economics No 2038, April. 
1952b. "The Measurement of Expectations: Abstract of Paper Presented at the Boston Meeting December 1951”, Econometrica, 20 (3): 481-482.

2001. Adventures of an Economist. Texere.

Modigliani, F., and A. Ando. 1963. "The Life Cycle Hypothesis of Saving Behavior: Aggregate Implications and Tests", American Economic Review, 53 (1 part 1): 55-84.

Modigliani, F., and R. Brumberg. 1954. "Utility Analysis and the Consumption Function: An Interpretation of Cross-Section Data", in Post-Keynesian Economics, ed. by K. Kuhihara, New Brunswick, NJ: Rutgers University Press, 388-436.

- 1955 (1958). "The Significance and Uses of Ex Ante Data: A Summary View", Proceeding of the Conference on Expectations, Uncertainty and Business Behavior, Social Science Research Council, October, 27-29.

. 1961. The Role of Anticipations and Plans in Economic Behavior and Their Use in Economic Analysis and Forecasting, Studies in Business Expectations and Planning No. 4, Bureau of Economic and Business Research, University of Illinois.

Modigliani, F., and F. E. Hohn. 1952. "Solutions to Certain Problems of Production Planning over Time Illustrating the Effect of Inventory Constraints", Appendix to Cowles Commission Paper: Economics no. 2038, April.

- 1955. "Planning Over Time and the Nature of the Expectations and Planning Horizon", Econometrica, 23 (1): 46-66.

Modigliani, F., and O. H. Sauerlender. 1955. "Economic Expectations and Plans of Firms in Relation to Short-Term Forecasting, Short-Term Economic Forecasting", in Studies in Income and Wealth, vol. 17, Princeton, NJ: Princeton University Press for the NBER, 299-303.

Modigliani, F., and R. J. Shiller. 1973. "Inflation, Rational Expectations and the Term Structure on Interest Rate", Economica, New Series, 40 (157): 12-43.

Modigliani, F., and R. Sutch. 1966. "Innovations in Interests Rate Policy", American Economic Review, 56 (1/2): 178-197.

- 1967. "Debt Management and the Term Structure of Interest Rates: An Empirical Analysis", Journal of Political Economy, 75: 569-589.

Morgenstern, O. 1935 (1976). "Perfect Foresight and Economic Equilibrium", in Selected Economic Writings of Oskar Morgenstern, ed. by A. Schotter, 151-167, New York: New York University Press.

Muth, J. 1961. "Rational Expectations and the Theory of Price Movements", Econometrica, 29 (3): 315-335.

Nash, J. 1950. "Equilibrium Points in n-Person Games", Proceedings of the National Academy of Sciences, 36: 48-49.

Rancan, A. 2013. "Modigliani's and Simon's Early Contribution to Uncertainty (19521960)", History of Political Economy, 45 (1): 1-38.

Research Project Under Task Order 358(01). 1953. Decision Making Project under Uncertainty, Eight Progress Report.

Sent, E. M. 2001. "Game Theorists versus Herbert Simon: Playing Games with Bounded Rationality", Journal of Economic Behavior and Organization, 44: 129-143.

2002. "How (Not) to Influence People: The Contrary Tale of John F. Muth", History of Political Economy, 34 (2): 291-319.

Sheffrin, S. M. 1996. Rational Expectations. Cambridge: Cambridge University Press.

Simon, H. 1945. "Review of Theory of Games and Economic Behavior, by John von Neumann and Oskar Morgenstern", American Journal of Sociology, 50: 558-60.

Simon, H. 1952, "Notes on Two Approaches to the Production Rate Problem", Cowles Commission Discussion Paper: Economics no. 2057, November. 
1954. "Bandwagon and Underdog Effects and the Possibility of Election Predictions", The Public Opinion Quarterly, 18 (3): 245-253.

. 1955. "A Behavioral Model of Rational Choice", Quarterly Journal of Economics, 69: 99-118.

— 1955 (1958). "The Role of Expectations in an Adaptive or Behavioristic Model", in Expectations, Uncertainty, and Business Behavior: Social Science Research Council, October 27-29, ed. by M. J. Bowman, New York: Social Science Research Council, 49-73.

- 1956a. "Reply: Surrogates for Uncertain Decision Problems", ONR Research Memorandum (38): 1-22.

- 1956b. "Dynamic Programming under Uncertainty with a Quadratic Criterion Function”, Econometrica, 24: 74-81.

- 1958. "Review of Games and Decisions: Introduction and Critical Survey", American Sociological Review, 23: 342-43.

- 1979. "Rational Decision Making in Business Organizations", American Economic Review, 69 (4): 493-513.

-1991. Models of My Life, New York: Basic Books.

- 2000. An Economy of Markets or Organizations?, Akron University, April.

Simon, H., and C. Holt. 1954. "The Control of Inventories and Production Rates: A Survey", Journal of the Operations Research Society of America, 2 (3): 289-301.

Tintner, G. 1941. “The Theory of Choice under Subjective Risk and Uncertainty.” Econometrica, 9 (July-October): 298-304.

Young, W., and W. Darity, Jr. 2001. "The Early History of Rational and Implicit Expectations", History of Political Economy, 33 (4): 773-812.

Young, W., R. Leeson, and W. Darity, Jr. 2004. Economics, Economists, and Expectations: Microfoundations to Macroapplications, New York: Routledge.

Ando, K. A. 1959. A Contribution to the Theory of Economic Fluctuations and Growth (1959), PhD Dissertation, Carnegie Tech.

- 1974. "Some Aspects of Stabilization Policies, the Monetarist Controversy, and the MPS Model”, International Economic Review, 15 (3): 541-571.

Ando, A., and F. Modigliani. 1957. "Tests of the Life Cycle Hypothesis of Savings: Comments and Suggestions", Bulletin of the Oxford University Institute of Statistics: 99-124.

- 1959. "Growth, Fluctuations and Stability." American Economic Review, 49 (2): 501-524.

- 1960. "The 'Permanent Income' and the 'Life Cycle Hypothesis' of Saving Behavior: Comparison and Tests", in Consumption and Saving, vol. 2, Wharton School of Finance and Commerce, Philadephia: University of Pennsylvania, 74-108.

- 1963. "The 'Life Cycle' Hypothesis of Savings: Aggregate Implications and Tests", American Economic Review, 33 (1), part 1: 55-84.

Arrow, K., and G. Debreu. 1954. "Existence of an Equilibrium for a Competitive Economy”, Econometrica, 22 (3): 265-290.

Backhouse, R. E., and M. Boianovsky. 2013. Transforming Modern Macroeconomics. Exploring Disequilibrium Microfoundations, 1956-2003, Cambridge, New York: Cambridge University Press.

Bain, J. S. 1956. Barriers to New Competition, Cambridge, MA: Harvard University Press.

Barnett W. A., and R. Solow. 2000, "An Interview with Franco Modigliani November 5-6 1999”, Macroeconomic Dynamics, 4: 222-256.

Béraud, A. 2018. "Modigliani et la question de l'existence d'un équilibre dans un modèle à prix flexible", HAL archives-ouvertes.fr: 1-38. 
Boianovsky, M., and H.-M. Trautwein. 2006. "Price Expectations, Capital Accumulation and Employment: Lindahl's Macroeconomics from the 1920s to the 1950s", Cambridge Journal of Economics, 30 (6): 881-900.

Brady D., Rose D. Friedman, 1947. "Savings and the Income Distribution", Studies in Income and Wealth, National Bureau of Economic Research, New York: 247-265.

Clower, R. 1965. "The Keynesian Counterrevolution: A Theoretical Appraisal”, in Theory of Interest Rates, ed. by F. H. Hahn and F. P. R. Brechling, London: Macmillan.

Dimand, R. W. 2014. James Tobin, U. K. Palgrave Macmillan.

de Scitovszky, T. 1941. "Capital Accumulation, Employment and Price Rigidity", Review of Economic Studies, 8 (2): 69-88.

Duarte, P. G., and G. T. Lima, eds. 2012. Microfoundations Reconsidered: The Relationship of Micro and Macroeconomics in Historical Perspective, Edward Elgar Cheltenam (UK) and Northampton (US).

Duesenberry, J. S. 1949. Income, Savings and the Theory of Consumer Behavior, Cambridge, MA: Harvard University Press.

Eisner, R. 1956. "Determinants of Capital Expenditures: An Interview Study", in Bureau of Economics and Business Research, University of Illinois.

- 1961. "Interview and Other Survey Techniques in the Study of Investment", in Problems of Capital Formation, Princeton, NJ: Princeton University Press.

. 1969. "Fiscal and Monetary Policy Reconsidered", American Economic Review, 59 (5): 897-905.

Fisher, S. 1988. "Recent Developments in Macroeconomics", Economic Journal, 98 (391): 294-339.

Friedman, M. 1957. A Theory of the Consumption Function, Princeton: Princeton University Press.

Gurley, J. G., and E. S. Shaw. 1960. Money in a Theory of Finance, Washington: The Brookings Institutions.

Hahn, F., 1955. "The Rate of Interest and General Equilibrium Analysis", Economic Journal, 65 (257), 52-66.

Hamburger, W. 1951. Consumption and Wealth, unpublished $\mathrm{PhD}$ dissertation, University of Chicago.

Hicks, J. 1939. Value and Capital: An Inquiry into Some Fundamental Principles of Economic Theory, Oxford: Oxford University Press.

Mehrling, P. 2011. The New Lombard Street: How the Fed Became the Dealer of Last Resort, Princeton, NJ: Princeton University Press.

Metzler, L. A. 1951. "Wealth, Savings and the Rate of Interest", Journal of Political Economy, 59 (2): 93-116.

Modigliani (Franco) Papers. David M. Rubenstein Rare Book and Manuscript Library, Duke University.

Modigliani, F. 1944a. "Liquidity Preference and the Theory of Interest and Money", Econometrica, 12, January: 45-88.

-1944b. The General Theory of Employment, Interest and Money under the Assumptions of Flexible Prices and of Fixed Prices, Thesis, Doctorate for Social Science New School for Social Research, Franco Modigliani Papers.

- 1947. "L'Organizzazione e la Direzione della Produzione in un'Economia Socialista," Giornali degli Economisti e Annali di Economia, 6: 441-514.

- 1949. "Fluctuations in the Saving- Income Ratio: A Problem in Economic Forecasting," Studies in Income and Wealth, National Bureau of Economic Research, no. 11, New York: 371-441. 
1955. "Theory of Money and Interest in the Framework of the General Equilibrium Analysis. Preliminary Notes", Franco Modigliani Papers.

- 1958. "New Developments on the Oligopoly Front", Journal of Political Economy, 66 (3), June: 215-232.

—. 1963. "The Monetary Mechanism and Its Interaction with Real Phenomena", The Review of Economics and Statistics, 45 (1), Part 2, Supplement, February: 79-107.

_ 1975. "The Life-Cycle Hypothesis of Savings Twenty Years Later", in Contemporary Issues in Economics, ed. by M. Parkin and A. R. Nobay, Manchester: Manchester University Press.

- 1980. The Life Cycle Hypothesis of Saving. Vol. 2. The Collected 812 Papers of Franco Modigliani, 6 vols, Cambridge MA: MIT Press.

- 1986. "Life Cycle, Individual Thrift, and the Wealth of Nations", American Economic Review, 76 (3): 297-313.

- 2001. Adventure of an Economist, New York, London: Texere.

Modigliani, F, and R. Brumberg. 1953 (1980). "Utility Analysis and Aggregate Consumption Functions: An Attempt at Integrating", in The Collected Papers of Franco Modigliani, Vol. 2: The Life Cycle Hypothesis of Saving, Cambridge, MA: MIT Press.

1953. Utility Analysis and Aggregate Consumption Functions: An Attempt at Integrating, Franco Modigliani Papers.

- 1954. "Utility Analysis and the Consumption Function: An Interpretation of Cross-Sectional Data", in Post Keynesian Economics, ed. by K. K. Kurhiara, New Brunswick: Rutgers University Press.

Modigliani, F., and F. E. Hohn. 1952. "Solutions to Certain Problems of Production Planning over Time Illustrating the Effect of Inventory Constraints", Appendix to Cowles Commission Paper, Economics No 2038, April.

- 1955. "Planning Over Time and the Nature of the Expectations and Planning Horizon", Econometrica, 23 (1): 46-66.

Mosak, J. 1944. General Equilibrium Theory in International Trade, Bloomington: Principia Press.

Ohlin, B. 1937. "Some Notes on the Stockholm Theory of Savings and Investment", Economic Journal, 47 (185): 53-69.

Patinkin, D. 1948. "Price Flexibility and Full Employment", American Economic Review, 38 (4): 543-564.

- 1956 (1965). Money Interests and Prices: An Integration of Monetary and Value Theory, 2nd ed., New York: Harper \& Row.

Rancan, A. 2014. "Modigliani's Comments on Sylos Labini's Theory of Unemployment (1956-58)", PSL Quarterly Review, 67: 269-282.

- 2015. "The Origin of the Sylos Postulate: Modigliani's and Sylos Labini's Contributions to Oligopoly Theory", Journal for the History of Economic Thought, September: 431-448, Cambridge University Press.

- 2019. "Income Distribution, Consumption, and Economic Growth in Italy: Kaldor's Theory versus the Life Cycle Hypothesis (1960s-1970s)", History of Political Economy, 51 (5): 867-900.

- 1950. "Effect of Income Concept upon Expenditure Curves of Farm Families", Conference on Research in Income and Wealth, 15: 131, 174.

Sylos Labini, P. 1956. Oligopolio e Progresso Tecnico, Milano: Giuffré.

Szenberg, M., and L. Ramrattan. 2008. Franco Modigliani a Mind That Never Rests, Palgrave Macmillan.

Tobin, J. 1947. A Theoretical and Statistical Analysis of Consumer Savings, unpublished $\mathrm{PhD}$ dissertation, Harvard University. 
Acosta, J., and G. Rubin. 2019. "Bank Behavior in Large-Scale Macroeconometric Models of the 1960s", History of Political Economy, 51 (3): 471-492.

Acosta, J., E. Pinzon-Fuchs 2019. "Peddling Macroeconometric Modeling and Quantitative Policy Analysis: The Early Years of the SSRC's Committee on Economic Stability, 1959-1963", OEconomia, 9 (3): 537-558.

Andersen, L. C., and J. L. Jordan. 1968. "Monetary and Fiscal Actions: A Test of Their Relative Importance in Economic Stabilization”, Federal Reserve Bank of St. Louis Review, 50 (November): 11-24.

Ando, A. K. 1974. "Some Aspects of Stabilization Policies, the Monetarist Controversy", International Economic Review, 15 (3): 541-571.

- 1981. "On a Theoretical and Empirical Basis of Macroeconometric Models", in Large-Scale Macro-Econometric Models, ed. by Kmenta and Ramsey, North-Holland Amsterdam.

Ando, A. K., and F. Modigliani. 1959. "Growth, Fluctuations and Stability", American Economic Review, 49 (2): 501-524.

Ando, A. K., and F. Modigliani. 1965. "The Relative Stability of Monetary Velocity and the Investment Multiplier”, American Economic Review, 55 (4): 693-728.

- 1969. "Econometric Analysis of Stabilization Policies", American Economic Review, 59 (2): 296-314.

-1975. "Some Reflections on Describing Structures of Financial Sectors", in The Brookings Model: Perspective and Recent Developments, ed. by G. Fromm and L. R. Klein, Amsterdam: North Holland, 524-563.

Ando, A. K., F. Modigliani, R. Rasche, and S. J. Turnovsky. 1974. "On the Role of Expectations of Price and Technological Change in an Investment Function", International Economic Review, 15 (2): 384-414.

Asso P. F., ed. 2007. Franco Modigliani. L'impegno civile di un'economista, Siena: Fondazione Monte dei Paschi di Siena.

Bach, G. L. 1963. "Introduction", Review of Economics and Statistics, 45 (1), Part 2, Supplement: 3-5.

Backhouse, R. E., and M. Boianovsky. 2013. Transforming Modern Macroeconomics: Exploring Disequilibrium Microfoundationss, 1956-2003, Cambridge and New York: Cambridge University Press.

Backhouse, R., and B. Cherrier. 2019. "The Ordinary Business of Macroeconometric Modelling: Working on the MIT-Fed-Penn Model (1964-1974)", History of Political Economy, 51 (3): 425-448.

Bishoff, C. 1968. "Lags in Fiscal and Monetary Impacts on Investment in Producers Durable Equipment”, Cowles Foundation Discussion Papers no 250, Cowles Foundation for Research in Economics, Yale University.

Blanchard, O. J. 2008. "Neoclassical Synthesis", in The New Palgrave: Dictionary of Economics, ed. by S. N. Durlauf and L. E. Blume, vol. 5, 2nd ed., London: Macmillan Press Ltd, 634-637.

Bodkin, R. G., L. Klein, and K. Marwah. 1991. A History of Macroeconometric Model-Building, Edwar Elgar.

Brainard, W. and J. Tobin, 1963. Financial Intermediaries and the Effectiveness of Monetary Controls", American Economic Review, 53 (2): 383-400.

- 1968. "Pitfalls in Financial Model Building", American Economic Review, 58 (2): 99-122.

Brayton, F., A. Levin, R. Lyon, and J. C. Williams. 1997. "The Evolution of Macro Models at the Federal Reserve Board", Carnegie-Rochester Conference Series on Public Policy, 47: 43-81. 
Brayton, F., and E. Mauskopf. 1985. "The Federal Reserve Board MPS Quarterly Econometric Model of the US Economy", Economic Modelling, 2 (3): 170-292.

. 1987. "Structures and Uses of the MPS Quarterly Econometric Model of the United States", Federal Reserve Bulletin, 93: 93-109.

Brayton, F., and P. Tinsley, eds. 1996. "A Guide to FRB/US A Macroeconometric Model of the United States." Version 1.0, October, 1-47.

Camurri, R. ed. 2019. I modesti consigli di un premio Nobel. Franco Modigliani. Rischio Italia. L'Italia vista dall'America (1970-2003), Donzelli Editore.

Cooper, J. P. and S. Fisher. 1972. "Stochastic Simulation of Monetary Rules in Two Macroeconomic Models", Journal of the American Statistical Association, Vol. 67 (340): 750-760.

Culberston, J. M. 1957. "The Term Structure of Interest Rates", The Quarterly Journal of Economics, 71 (4): 485-517.

de Leeuw, F., and E. M. Gramlich. 1968. "The Federal Reserve: MIT Econometric Model”, Federal Reserve Bulletin, January: 11-40.

- 1969. "The Channels of Monetary Policy: A Further Report on the Federal Reserve: MIT Model”, The Journal of Finance, 24 (2): 265-290.

de Menil, G., and J. J. Enzler. 1972. "Prices and Wages in the FRB_MIT-Penn Econometric Model", O. Eckstein, ed. The Econometric of Price Determination Conference October 30-31, Board of Governors of the Federal Reserve System, Washington, D.C.: 277-308, Sponsored by the Governors of the FED and SSRC.

Dimand, R. W. 2014. James Tobin, Palgrave Macmillan.

Dimand, R., and H. Hagemann, 2019. "Jacob Marschak and the Cowles Approaches to the Theory of Money and Assets". Cowles Foundation Discussion Paper no 2196. https:// www.researchgate.net/publication/335677051. Last access November 29, 2019.

Duarte, P. G and G. Tadeu Lima ed. Microfoundations Reconsidered: The Relationship of Micro and Macroeconomics in Historical Perspective. Cheltenham, UK, Northampton MA, US. Edward Elgar Publishing.

Duesenberry, J. C. 1958. Business Cycles and Economic Growth, New York: McGraw-Hill Book Co. Ltd.

Eisner, R. 1969. "Fiscal and Monetary Policy Reconsidered", American Economic Review, 59 (5): 897-905.

Friedman, B. 1975. "Rational Expectations Are Really Adaptive After All," unpub. paper, Harvard Univ.

Friedman, M. 1968. "The Role of Monetary Policy”, American Economic Review, 58 (1): $1-17$.

. 1970. “A Theoretical Framework for Monetary Analysis”, in Milton Friedman's Monetary Framework: A Debate with His Critics, Chicago and London: University of Chicago Press, 1-62.

- 1977. "The Monetarist Controversy: Discussion by Milton Friedman and Franco Modigliani”, Federal Reserve Bank of San Francisco Economic Review, Supplement, Spring: 5-27.

Friedman, M., and A. J. Schwartz. 1963a. Monetary History of the United States, 1867-1960", Princeton, NJ: Princeton University Press.

. 1963b. "Money and Business Cycles", The Review of Economics and Statistics, 45 (1), part 2: 32-64.

Friedman, M., and D. Meiselman. 1963. "The Relative Stability of Monetary Velocity and the Investment Multiplier in the United States, 1987-1958”, in Stabilization Policies: Commission on Money and Credit, Englewood Cliffs, NJ: Prentice-Hall, 165-268.

Forder, J. 2014. Macroeconomics and the Phillips Curve Myth, Oxford: Oxford University Press. 
Fromm, G., and L. R. Klein eds., 1975. The Brookings model: Perspective and Recent developments, Amsterdam: North Holland.

Goldfeld, S. M. 1966. Commercial bank behavior and economic activity: a structural study of monetary policy in postwar United States, Amsterdam, North Holland publishing company.

Goodfriend, M., and R. King. 1997. "The New Neoclassical Synthesis and the Role of Monetary Policy”, NBER Macroeconomics Annual 1997, vol. 12, Cambridge: MIT Press, 231-296.

Gordon, J. R., ed. 1974. Milton Friedman's Monetary Framework. A debate with his critics, University Chicago Press.

Gramlich, M. Edward. 1971. "The Usefulness of Monetary and Fiscal Policy as Discretionary Stabilization Tools." Journal of Money, Credit and Banking, 3 (2 part 2): 506-32.

Hagemann, H. 2005. "The Influence of Jacob Marschak, Adolph Lowe, and Hans Neisser on the Formation of Franco Modigliani's work", in Franco Modigliani and the Keynesian Legacy, Schwartz Center Conference at the New School University, New York, April $1-25$.

Hall, R. 1977. "Investment, Interest Rates, and the Effects of Stabilization Policies", Brookings Papers on Economic Activity, 1: 61-103.

Hall, R. E. and T. J. Sargent. 2018. "Short and Long Run Effects of Milton Friedman's Presidential Address". Journal of Economic Perspectives, vol. 32 (1): 121-134.

Hetzel, R. L. 2008. The Monetary Policy of the Federal Reserve: A History, Cambridge: Cambridge University Press.

Hicks, J. 1939. Value and Capital. An Inquiry into Some Fundamental Principles of Economic Theory. Oxford: Clarendon Press.

Holt, C. 1970. “Job Search, Phillips' Wage Relation, and Unemployment Influence: Theory and Evidence", in Microeconomic Foundations of Employment \& Inflation Theory, ed. by E. Phelps, Macmillan, 53-123.

Holt, C. C., F. Modigliani, J. F. Muth, and H. Simon. 1960. Planning Production, Inventories and Work Forces, Prentice-Hall.

Intriligator, M. D. 1978. Econometric Models, Techniques, and Applications, Oxford: North Holland.

Klein, L. R. 1947. Klein, L., 1947 (1966). The Keynesian revolution, New York: Mcmillan.

Klein, L. R. 1964. "A Postwar Quarterly Model: Description”, Models of Economic Determination, NBER Studies Income and Wealth no. 28, Princeton: Princeton University Press.

Klein, L. R., and A. S. Goldberger. 1955. An Econometric Model for the United States, 19291952. Amsterdam: North Holland.

Mankiw, N. G. 1990. “A Quick Refresher Course in Macroeconomics”, Journal of Economic Literature, XXVIII: 1645-1660.

- 2006. "The Macroeconomist as Scientist and Engineer", The Journal of Economic Perspective, 20 (4), Fall: 29-46.

Markowitz, H. 1952. "Portfolio Selection", Journal of Finance, 7 (1): 77-91.

Mehrling, P. 1998. "The Money Muddle: The Transformation of American Monetary Thought”, 1920-1970, History of Political Economy, 30 (Supplement): 293-306.

- 2002. "Don Patinkin and the Origin of Postwar Monetary Orthodoxy", European Journal of Economic Thought, 9 (2): 161-185.

- 2010. "A Tale of Two Cities", History of Political Economy, 42 (2): 201-219.

. 2011. The New Lombard Street: How the Fed Became the Dealer of Last Resort, Princeton: Princeton University Press. 
. 2014. "MIT and Money", in MIT and the Transformation of American Economics, ed. by E. R. Weintraub History of Political Economy 46 (Supplement): 177-197.

Meltzer, A. 2003. A History of the Federal Reserve, Volume 1: 1913-1951, Chicago: Chicago University Press.

Minsky, H. P. 1963. "Comments on Friedman's and Schwartz' Money and the Business Cycles", The Review of Economic Statistics 45 (1), part 2: 64-78.

Modigliani (Franco) Papers. David M. Rubenstein Rare Book and Manuscript Library, Duke University.

Modigliani, F. 1944. "Liquidity Preference and the Theory of Interest and Money", Econometrica, 12, January: 45-88.

- 1955. "Theory of Money and Interest in the Framework of the General Equilibrium Analysis. Preliminary Notes", Franco Modigliani Papers.

- 1958. "New Developments on the Oligopoly Front", Journal of Political Economy, 66 (3): 215-232.

- 1963. "The Monetary Mechanism and Its Interaction with Real Phenomena", Review of Economics and Statistics, 45 (1), part 2 Supplement, 79-107.

- 1964. "Some Empirical Tests of Monetary Management and of Rules Versus Discretion", Journal of Political Economy, 72 (3): 211.

- 1966. "Outline of Proposal Research Project on the Links between Monetary Policy and Aggregate Demand", To the Members of the Subcommittee on the Monetary Mechanism of the Social Science Research Council Committee on Economic Stabilization (Bank of Italy Historical Archive.): 1-7.

Modigliani, F. 1971. "Monetary Policy and Consumption: Linkages via Interest Rate and Wealth Effects in the MPS model." Federal Reserve Bank of Boston Conference Series no 5 (June): 9-84. pdfs.semanticscholar.org/eb34/e1fd0e32274568f20f70d-6296c3b0001369a.pdf.

- 1975. "The Channels of Monetary Policy in the Federal Reserve-MIT-University of Pennsylvania Econometric Model of the United States" in Modelling the Economy Based on Papers Presented at the Social Science Research Council's Conference on Economic Modelling, July 1972, ed. by G. A. Renton, London: Heinemann Educational Book, 240-267.

- 1977a. "The Monetarists Controversy or, Should We Forsake Stabilization Policies?", American Economic Review, 67 (2): 1-19.

_. 1977b. "The Monetarist Controversy: A Seminar Discussion: Paper by Franco Modigliani”, Federal Reserve Bank of San Francisco Economic Review, Supplement, Spring.

_ 1980-1989. The Collected Papers of Franco Modigliani (5 voll.), ed. by A. Abel, Cambridge, MA: MIT Press.

- 1986. The Debate over Stabilization Policy, Cambridge: Cambridge University Press. . 1987. Macroeconomics and Finance: Essays in Honors of Franco Modigliani, ed. by R. Dornbusch, S. Fisher, and J. Bossons, Cambridge, MA: MIT Press.

. 2001. Adventure of an Economist, New York and London: Texere.

Modigliani, F., and A. K. Ando. 1976. "Impacts of Fiscal Actions on Aggregate Income and the Monetarist Controversy: Theory and Practice" (with the assistance of J. Giangrande). In Studies in Monetary Economics, vol. 1, ed. by Jerome L. Stein, New York: American Elsevier, 17-42.

Modigliani, F., and R. Brumberg. 1953 (1980). "Utility Analysis and Aggregate Consumption Functions: An Attempt at Integrating", in The Collected Papers of Franco Modigliani, Vol. 2: The Life Cycle Hypothesis of Saving, Cambridge, MA: MIT Press.

- 1954. "Utility Analysis and the Consumption Function: An Interpretation of Cross-Sectional Data", in Post Keynesian Economics, ed. by K. K. Kurhiara, New Brunswick: Rutgers University Press. 
Modigliani, F., and L. Papademos. 1975. "Targets for Monetary Policy in the Coming Year", Brooking Papers on Economic Activity, 1: 141-165.

Modigliani, F., R. Rasche, and P. J. Cooper. 1970. "Central Bank Policy, the Money Supply and the Short Term Rate of Interest", Journal of Money, Credit and Banking, 2 (2): 166-218.

Modigliani, F., and R. Sutch. 1966. "Innovations in Interest Rate Policy", American Economic Review, 56 (1/2): 178-197.

1967. "Debt Management and the Term Structure of Interest Rates: An Empirical Analysis", Journal of Political Economy, 75: 569-589.

Modigliani F., Shiller R. J., 1973. "Inflation, Rational Expectations and the Term Structure on Interest Rate", Economica. New Series 40 (157): 12-43.

Modigliani, F., and E. Tarantelli. 1973. "The Consumption in a Developing Economy and the Italian Experience", American Economic Review, 65 (5): 825-842.

Nerlove, M. 1966. "Tabular Survey of Macro-Econometric Models", International Economic Review, 7 (2): 127-175.

Patinkin, D. 1956 (1965). Money Interests and Prices: An Integration of Monetary and Value Theory, 2nd edn, New York: Harper \& Row.

Phelps, eds. E. 1970. Microeconomic Foundations of Employment and Inflation Theory, New York: W. W. Norton \& Company, Inc.

Pierce, J. L. and J. J. Enzler. 1974. "The effects of external inflationary shocks. Brookings Papers on Economic Activity, 1: 13-61.

Rancan, A. 2015. "The Origin of the Sylos Postulate: Modigliani's and Sylos Labini's Contributions to Oligopoly Theory", Journal for the History of Economic Thought, (September), Cambridge University Press: 431-448.

- 2019. "Empirical Macroeconomics in a Policy Context: The Fed-MIT-Penn versus the St. Louis Model (1965-1975)", History of Political Economy, 51 (3): 449-470.

- 2020. "The 'place of the Phillips curve' in Macroeconometric Models: The Case of the Fed's Macroeconometric Model (1966-1980s)". https://papers.ssrn.com/sol3/ papers.cfm?abstract_id $=3414864$.

Rasche, R. H, and H. T. Saphiro. 1968. "The F.R.B.-M.I.T. Econometric Model: Its Special Features". The American Economic Review, 58 (2): 123-149.

Rees, A. 1970. "The Phillips Curve as a Menu for Policy Choice", Economica, 37 (147): 227-238.

Romani, R. 2018. "On Science and Reform: The Parable of the New Economics, 1960s-1970s", The European Journal of the History of Economic Thought: 1-33.

Samuelson, P. A. 1987. The 1985 Nobel Prize in Economics, in Macroeconomics and Finance: Essays in Honor of Franco Modigliani, ed. by R. Dornbusch, S. Fisher, and J. Bossons, Cambridge, MA: MIT Press, 29-35.

- 2005. Franco: A Mind Never at Rest, Franco Modigliani between Economic Theory and Social Commitment, Proceeding of the International Conference Organized by the Accademia Nazionale dei Lincei, Roma, February 17-18, Banca Nazionale del Lavoro, Quarterly Review, 58: 5-10.

Smith, G., and J. Tobin. 1975. "Discussion (on Some Reflections on Describing Structures of Financial Sectors)", in The Brookings Model: Perspective and Recent Developments, ed. by G. Fromm and L. R. Klein, Amsterdam: North Holland, 564-572.

Stein, H. 1969. The Fiscal Revolution, Chicago: University of Chicago Press.

Szenberg, M., and L. Ramrattan. 2008. Franco Modigliani: A Mind That Never Rests, Basingstoke, England, and New York: Palgrave Macmillan. 
Tobin, J. 1956. “The Interest Elasticity of the Transactions Demand for Cash”, Review of Economics and Statistics, 38 (3): 241-247.

Tobin, J. 1958. "Liquidity Preference as Behavior Towards Risk," Review of Economic Studies, 25 (1): 65-86.

Tobin, J. and W. Brainard. 1968. "Pitfalls in Financial Model Building," American Economic Review, 58 (2): 99-122.

Tobin, J. 1969. "A General Equilibrium Approach to Monetary Theory," Journal of Money, Credit, and Banking, 1 (1): 15-29.

Visco, I. 1991. "A new round of US model comparisons: a limited appraisal” in L. R. Klein ed. Comparative Performancec of U.S. Econometric models, Oxford University Press, New York, pp. 289-315. 